\title{
Catching-up in the global factory: Analysis and policy implications
}

\author{
Peter J. Buckley ${ }^{1}$, \\ Roger Strange ${ }^{2}$, \\ Marcel P. Timmer ${ }^{3}$ and \\ Gaaitzen J. de Vries ${ }^{3}$ \\ ${ }^{1}$ Leeds University Business School, Maurice
Keyworth Building, University of Leeds,
Leeds LS2 9JT, UK; ${ }^{2}$ University of Sussex Business
School, Jubilee Building, University of Sussex,
Brighton BN1 9SL, UK; ${ }^{3}$ Faculty of Economics and
Business, University of Groningen, P.O. Box 800,
9700 AV Groningen, The Netherlands
}

Correspondence:

G) de Vries, Faculty of Economics

and Business, University of Groningen,

P.O. Box 800, 9700 AV Groningen,

The Netherlands

e-mail: g.j.de.vries@rug.nl
Received: 24 April 2019

Revised: 6 December 2019

Accepted: 19 December 2019

Online publication date: 14 February 2020

\begin{abstract}
MNEs shape the location of activities in the world economy, linking diverse regions in what has been called the global factory. This study portrays the evolution of incomes and employment in the global factory using a quantitative input-output approach. We find emerging economies forging ahead relative to advanced economies in income derived from fabrication activities, handling the physical transformation process of goods. In contrast, convergence in income derived from knowledge-intensive activities carried out in pre- and postfabrication stages is much slower. We discuss possible barriers to catching-up and policy implications for emerging economies in developing innovation capabilities, stressing the pivotal role of MNEs.
\end{abstract}

Journal of International Business Policy (2020) 3, 79-106.

https://doi.org// 0.1057/s422/4-020-00047-9

Keywords: global factory; convergence; fabrication activities; knowledge-intensive activities; emerging economies

The online version of this article is available Open Access

\section{INTRODUCTION}

The past 30 years have witnessed the phenomenal growth of global production networks and significant changes in the location of manufacturing-related activities worldwide, away from the advanced economies and towards the emerging economies. The resultant international division of labor has been termed the global factory (GF) (Buckley, 2009a, 2009b, 2011; Buckley \& Ghauri, 2004). The activities in the GF are linked by cross-border flos of intermediate products and knowledge as part of complex strategies by multinational enterprises (MNEs) to reduce location and transaction costs ${ }^{1}$. This refashioning of the global economy has been effected through foreign investment and outsourcing by MNEs from advanced countries to emerging economies, as well as the arrival and growth of indigenous MNEs in the emerging economies (Buckley \& Strange, 2015). One could easily describe developments in this period as a process of convergence and catch-up, perhaps even leapfrogging, of emerging economies, exemplified by the growth of innovation hubs, such as in regions around Bangalore and Shanghai (Chaminade \& Vang, 2008; Lorenzen \& Mudambi, 
2013), and success stories of Chinese, Indian and Brazilian firms (such as Huawei, Haier, Tata or Marcopolo) becoming global players operating at the technological frontier. Moreover, many MNEs from advanced economies (AMNEs) are reported to have offshored not just production and assembly activities but also more challenging and rewarding activities, such as human resource management, customer support, and accounting and finance, as well as R\&D and design. AMNEs have also offshored associated technical, managerial and marketing knowledge contributing to the development of capabilities within the emerging economies, not only at the level of production but also in creating the knowledge behind products (Pyndt \& Pedersen, 2006; Dossani \& Kenney, 2007; Mudambi, 2008; Gospel \& Sako, 2008; Lewin, Massini, \& Peeters, 2009; Lewin, Kenney, \& Murmann, 2016; Gereffi \& Fernandez-Stark, 2016; Belderbos, Sleuwaegen, Somers, \& De Backer, 2016; Mudambi, 2018).

In a recent popular book, Baldwin (2016) draws out the economic implications of the evolving GF. He concludes that the unbundling of value-chain activities has led to the deindustrialization of the advanced economies, to the industrialization of a selection of emerging economies, and to a convergence of income levels between the advanced and the emerging economies. Some initially poor countries grew fast through quickly enlarging the scale of manufacturing activities, providing gainful employment opportunities for an underutilized workforce. Activities in emerging economies substituted in large part for activities that were previously carried out by workers in advanced countries, negatively affecting local demand for low-skilled jobs in manufacturing industries. Meanwhile, demand for knowledge workers who are complementary to the emergence of the GF, such as managers, ICT specialists and marketers, increased in all regions. Baldwin refers to this period in world history as a period of the "Great Convergence". ${ }^{2}$ The use of the adjective "Great" is debatable, however, as cross-country gaps in income are still large: in 2017, gross domestic product (GDP) per capita in Brazil, China, India, Indonesia or Mexico was less than one-third of the level in the United States. ${ }^{3}$ Moreover, there are still a sizeable number of low-income countries that have no, or at best a shallow, connection to the GF, forgoing the potential benefits from participating in the new international division of labor. Some observers even posit a "middle-income trap", as growth in emerging economies appears to be slowing down after reaching a certain income threshold that is well below the incomes at the global frontier (Eichengreen, Park, \& Shin, 2014; Bulman, Eden, \& Nguyen, 2017).

What is behind the lack of income convergence in the global economy? In an influential study, Rodrik (2012) found that this is not so much due to lagging productivity growth but due to the lack of catch-up in the scale of modern manufacturing. He documents so-called 'unconditional convergence', finding rapid catch-up in labor productivity levels (output per worker) in manufacturing for poorer countries, regardless of their geography, institutions, or other country-specific characteristics. Yet, catch-up in income (aggregate GDP per capita) is much weaker, as the scale of manufacturing grows only slowly. Rodrik (2014, 2018a) hypothesizes that modern technologies, such as robotization, are substituting for unskilled labor such that industrialization benefits a small group of highly productive firms that generate limited employment opportunities. Rodrik's hypothesis suggests that, once countries start up manufacturing activities, rapid productivity growth will automatically follow through the transfer of knowledge and modern machinery from the global frontier. Yet, there is an abundant literature, discussed later in this paper, that argues that technology catch-up is not a simple linear process. Instead, it is governed by different forces that vary at different rungs of the technology ladder. This is suggestive of a more nuanced study of convergence and catch-up in the world economy than provided by Baldwin (2016) or Rodrik (2012). There is a clear need to distinguish between catch-up in productivity and catch-up in the scale of activities, as well as deeper study of different types of activity. In this paper, we provide such an analysis, asking, and answering, two straightforward questions. First, how fast was growth in income and productivity of workers in emerging economies that participated in the GF, compared to workers in advanced economies? Second, does growth vary across different types of activities in the GF? These questions are worthy of further investigation, as they explicitly link MNE behavior and GF dynamics to income generation and distribution around the world. We will for the first time quantify the speed and depth of 
convergence in both types of activities in the GF, and discuss implications for policy.

Our findings suggest a nuanced understanding of the convergence process in the GF. We define the GF as the ensemble of all activities related to the production of manufacturing goods. These activities can take place in MNEs or national firms, and can be classified in the manufacturing sector as well as other sectors of the economy (such as business services) that contribute to the production process. One main finding is that productivity growth in the GF was much higher in our set of emerging economies (including, among others, China and India) than in our set of advanced economies (including, among others, Europe, Japan and the United States). Yet, productivity started to grow from an extremely low level such that a major productivity gap still remains. Next, we focus on the scale of activities.

A key distinction in our analysis is between fabrication activities and knowledge-intensive (KI) activities. Fabrication activities refer to the traditional manufacturing and assembly stages within global production networks involving the physical transformation process of goods. We distinguish these from knowledge-intensive (KI) activities that include pre-production activities (such as R\&D and design) as well as post-production (marketing and distribution) activities. It is well known that remuneration for KI activities is much higher than for fabrication activities, as illustrated in the wellknown "smile curve" first formulated by Stan Shih of Acer in 1992 (Mudambi, 2008; Park, Nayyar, \& Low, 2013). Our second main finding is that there is strong catching-up and occasionally forging ahead in the scale of fabrication activities by emerging economies over the past 3 decades. Yet, convergence in the scale of KI activities in the GF is much slower, in particular in machinery, chemicals and pharmaceutical products. Low productivity levels, combined with the limited scale of KI activities carried out in the GF, results in an income per head of the population in emerging economies of only about a third of the level of advanced economies as of 2014. Our findings do not gainsay that there are many case studies of successful MNEs in emerging economies that have been able to graduate. Our results suggest rather that these are the exceptions and not the rule, hinting to the existence of major barriers to widespread technology acquisition and adoption by indigenous firms in emerging economies. In line with Rodrik (2012), we argue that it is the combination of convergence in productivity and scale in the GF that ultimately determines a country's success in catching-up in GDP per capita.

The paper proceeds as follows. We first provide a theoretical background to convergence dynamics in the GF, drawing upon theories from International Business as well as from International Economics. We stress that fabrication activities require investment, and the development of capabilities, in imitative production activities, basically operating and replicating existing technologies. KI activities require innovation capabilities which are typically developed only after, and based on, previously developed production capabilities. This is not a simple evolutionary process and many impediments to the catching-up in innovative activities have been identified in the literature as will be discussed. Next, we outline the decomposition method and discuss data sources to trace the location and characteristic of activities in the GF. Our approach is highly data-intensive, but has a very clear intuition, using information on trade and employment across industries and countries to map the GF. Importantly, we not only take account of workers in the manufacturing sector but also in other sectors of the economy. This is crucial because an increasing share of the activities related to the production of manufacturing goods takes place outside the manufacturing sector, in a process known as "servicification" (Pilat, Cimper, Olsen, \& Webb, 2008; Crozet \& Millet, 2017). Standard statistics that are traditionally used to track the GF typically refer only to the manufacturing sector and will not be able to identify the set of services activities that is intertwined with manufacturing activities. These services activities will, however, be included in our analysis which traces all inputs that are needed in every stage of production, irrespective of whether it takes place inside or outside the manufacturing sector. Arguably, advanced economies have a comparative advantage in such services activities, such that an analysis relying on standard manufacturing statistics (such as in Rodrik, 2012) is prone to (grossly) underestimate the incomes earned by advanced countries in the GF, and subsequently overestimate the convergence speed of emerging economies. We proceed by presenting our key findings on convergence trends between advanced and emerging economies for detailed 
product groups as well as for the aggregate, carefully distinguishing between catch-up in productivity and catch-up in scale. We believe the results carry important policy implications regarding the generation and distribution of income around the world, and these are further discussed in the closing sections.

\section{THEORETICAL BACKGROUND}

In this section, we will summarize two strands of literature that help in better understanding the dynamics in the GF that we document in this paper. The theory of comparative advantage, as developed in the field of international economics, highlights the role of country-level differences in factor endowments and technology in determining the location of activities in the world economy. Originally developed for a world with trade in final goods, it has recently been reformulated to also account for what is called "trade in tasks", making it highly relevant for analyses of the GF. Next, we discuss theories of international technology diffusion and innovation as developed in the International Business literature. These focus on the dynamic development of technology adoption by firms, problematizing the simple evolution from imitation to innovation as suggested by theories of international trade and discussing the various impediments to catching-up in innovative activities in emerging economies.

\section{The Comparative Advantage of Nations in the Global Factory}

The cornerstone of theories on international trade and the location of production is David Ricardo's theory of comparative advantage. Informally put, the theory predicts that when barriers to international trade are lowered, countries produce and export more of the goods where they have a comparative advantage. Nations can derive comparative advantage from two sources: differences in resource endowments and differences in technology. Comparative advantage theory focuses on differences in resource endowments, and Ricardo's theory was originally formulated in terms of final goods (wine and cloth) assuming that all stages in the production of a good took place in a single country.

Is his insight still valid in a world with increasing international fragmentation of production, in short "unbundling" as per Baldwin (2016)? Baldwin and Evenett (2015) argue that unbundling does not alter the underlying logic of Ricardo's theory. Comparative advantage theory, suitably reformulated to account for trade in tasks alongside trade in goods, is useful for understanding the location of activities in the GF. In the GF, countries become more specialized in carrying out particular stages of the production process, based on their comparative advantage. To see this in a simple example, consider two goods, A and B, and two countries, one abundant in skilled labor (say Germany) and the other abundant in unskilled labor (say Poland). Good A is skilled labor-intensive and B is unskilled labor-intensive, such that Germany initially has a comparative advantage in $\mathrm{A}$ and Poland in B. Following Ricardo's theory, when trade costs decline, Germany is expected to produce more A and export this to Poland, while Poland is expected to produce more $\mathrm{B}$ and export this to Germany. Now assume that the production process can be unbundled into separate activities (also referred to as tasks): $\mathrm{A}$ into $\mathrm{A} 1$ and $\mathrm{A} 2$, and $\mathrm{B}$ into $\mathrm{B} 1$ and $\mathrm{B} 2$. And suppose that $\mathrm{A} 1$ and $\mathrm{B} 1$ are skill-intensive relative to both $\mathrm{A} 2$ and $\mathrm{B} 2$. Following the logic of comparative advantage, the expectation is that activities A1 and B1 will be carried out in Germany, while activities A2 and B2 in Poland. In fact, the effects of comparative advantage are magnified when fragmentation is possible. Before the unbundling, some unskilled German workers were employed in the unskilled stage of production of A since this was bundled with the skilled stage. After the unbundling, each country is fully specialized according to its comparative advantage in tasks, rather than in products. Timmer, Miroudot, and de Vries (2019) provide evidence that corroborates the validity of the Ricardian insight in a world with unbundling. They find a strong international division of labor in the world economy, with different tasks being carried out by participants in global production networks, dubbing this a process of functional specialization in trade. For example, they show that Mexico and Poland have a revealed comparative advantage in exporting fabrication activities, Italy and South Korea in marketing activities, the Netherlands and the US in management activities and Germany and Sweden in R\&D activities. 
One could argue that the new patterns of specialization in the global economy reinforces the importance of national factor endowments and might postpone the graduation of poor countries into higher value-added activities. As noted early on by Porter (1990): "The central task facing developing countries is to escape from the straitjacket of factor-driven national advantage... where natural resources, cheap labor, locational factors and other basic factor advantages provide a fragile and often fleeting ability to export." (Porter, 1990: 675 ). Understanding the dynamic process of accumulating knowledge resources is key to the convergence process. This has been the subject of theories of international technology diffusion and innovation, as developed in the Innovation and International Business literature.

\section{International Technology Diffusion and Innovation}

Summarizing a large body of literature, Fu, Pietrobelli, and Soete (2011: 1604) emphasize that "innovation is costly, risky, and path-dependent... In principle, if innovations were easy to diffuse and adopt regardless of their nature and type, a technologically backward country could catch-up rapidly by absorbing the most advanced technologies. [But] technology diffusion and adoption is neither costless nor unconditional." In another overview, Fagerberg, Srholec, and Verspagen (2010) reach similar conclusions. Numerous studies have suggested a clear sequence in which innovation capabilities are developed only after, and based on, previously developed production capabilities. This stages hypothesis has been advanced in the 1980s by scholars studying the industrialization and convergence process in East Asia (Westphal, 1982; Evenson, 1990; Lall, 1992; Amsden \& Tschang, 2003). A more recent example is provided by an indepth study of catching-up by emerging economy multinationals (EMNEs) in the wind turbine industry (Awate, Larsen, \& Mudambi, 2012). AMNEs established wind turbines and the grid network by around 1990. Within 5 years, an EMNE from India (Suzlon Energy Inc) entered the industry. Suzlon acquired the output capabilities within a short time span, and captured a substantial share of the global market. However, detailed investigation of the breadth and depth of patenting data in the wind turbine industry reveals that, while Suzlon caught up in terms of production capabilities, it has not (yet) done so in innovation capabilities (Awate et al., 2012). In broad terms, we may identify three sets of issues which underpin the slow process of catch-up in KI activities: time lags due to required organizational learning (absorption) by indigenous firms; constraints on external technology acquisition; and the slow pace of political institutional change.

First, path dependency is important in that indigenous emerging economy (EE) firms clearly need to develop their own production capabilities before they are able to upgrade and develop the capabilities for KI activities (Leonard-Barton, 1992; Lall, 1992, 1993; Figueiredo, 2002; Altenburg, Schmitz, \& Stamm, 2008). There is thus a necessary time lag between EE firms mastering the requirements of undertaking production activities and developing the capabilities required for KI activities, due to the necessities of organizational learning (Teece, 1986; Dixon \& Meyer, 2014). As Lundvall (1992: 1) has noted, 'the most fundamental resource in the modern economy is knowledge and, accordingly, the most important process is learning.' This resonates with the notion of economic development as a process of "self-discovery" (Hausman \& Rodrik, 2003). Cohen \& Levinthal (1990) highlight that the absorptive capacity of local firms is a limiting factor in effective assimilation of technologies. Firms which are over-reliant on external technology often have limited internal capabilities (Levinthal \& March, 1993), hindering catch-up in KI activities.

Second, many emerging economies have historically endeavored to accelerate economic development through opening up to inward foreign direct investment (FDI) by AMNEs in the expectation that the FDI will not only provide additional employment and output but will also lead to the transfer of advanced technological, management and managerial expertise to indigenous firms both directly and indirectly through various spillover effects (Crespo \& Fountoura, 2007). Broadly speaking, there are two channels of foreign technology acquisition for local firms in EEs. One is that the firms license the technology from overseas. This strategy has been successfully applied in East Asia. For example, Kim (1998) showed how South Korean automaker Hyundai built upon the experience in production of cars under a Ford license to acquire innovation strengths, eventually developing fully indigenous models. Hobday (2001) documents the success of similar imitation strategies by Taiwanese electronics firms. Kumaraswamy, Mudambi, Saranga, and Tripathy (2012) detail indigenous auto component firms that adapted to 
market liberalization in India, and conclude that the initial focus on technology licensing/collaborations and joint ventures with AMNEs laid the foundations for the integration of the domestic industry into the global production networks of the AMNEs. More recently, Turkina and van Assche (2018) propose a general framework to evaluate how global connections between local clusters may strengthen local innovation outcomes. Poor levels of intellectual property (IP) protection were evident in many emerging economies in the past (Maskus, 2000), which provided a severe disincentive to the transfer of valuable technology and intellectual property (Seyoum, 1996; Smarzynska, 2002; Belderbos, Leten, \& Suzuki, 2013). There is evidence that IP protection has improved over time in many emerging economies, and that this improvement has led to greater inflows of FDI (Khoury \& Peng, 2011; Amokuse \& Yin, 2010). Yet, it is unlikely that foreign licensors could be found for the types of superior knowledge-based assets and tacit capabilities (e.g., sophisticated technology, well-known brand names, marketing and management expertise) that would underpin rapid catch-up (Pyndt \& Pedersen, 2006; Elia, Munjal, \& Scalera, 2016).

An alternative possibility is that local firms access the requisite technology through the acquisition of suitable target firms in advanced economies (and hence become EMNEs). There is an extensive and ever-growing literature suggesting that latecomer EMNEs use internationalization as a "springboard" to acquire strategic assets (e.g., brands, managerial expertise, technology and distribution channels) overseas, while also reducing their vulnerability to institutional constraints at home (see, e.g., early contributions by Child \& Rodrigues, 2005; Mathews, 2006; Luo \& Tung, 2007). Hennart $(2009,2012)$ has argued that EMNEs typically have preferential access to "complementary local resources" (including land, labor, natural resources, infrastructure, and distribution assets). This preferential access enables the EMNEs to enjoy market power at home, which in turn provides them with the profits necessary to acquire foreign assets through FDI and/or obtain those assets from foreign MNEs in exchange for access to the local resources. More recently, there have been signs of $\mathrm{R} \& \mathrm{D}$ internationalization by EMNEs (Li \& Kozhikode, 2009; Awate, Larsen, \& Mudambi, 2015; Papanastassiou et al. 2019). Awate et al. (2015) report that EMNEs aim to access knowledge from R\&D subsidiaries in advanced economies for innovation catch-up, and that their $R \& D$ internationalization is grounded in the firms' overall catch-up strategies to obtain parity with industry leaders. They conclude that the innovative capabilities of EMNEs develop more slowly and with greater difficulty than those of AMNEs. This suggests once again that external technology sourcing is not necessarily a fast track to catching-up in KI activities.

Third, Fu et al. (2011: 1204) argue that "despite the potential offered by globalization and a liberal trade regime, the benefits of international technology diffusion can only be delivered with parallel indigenous innovation efforts and the presence of modern institutional and governance structures and conducive innovation systems." This highlights the importance of the national innovation systems for technological development (Lundvall, 1992; Edquist, 1997; Carlsson, 2006; Lundvall, 2007; Samara, Georgiadis, \& Bkouros, 2012; Belderbos et al., 2013; Fan, Li \& Chen, 2017). More broadly, it is now established wisdom that institutions matter for development (North, 1991), and that the absence of effective institutions will impede the ability of emerging economies (and indeed any economy) to mobilize economic resources and to regulate market exchanges. This has given rise to the concept of "institutional voids" (Khanna \& Palepu, 1997), which describes the under-developed or inefficient nature of many regulatory systems, capital markets, corporate governance mechanisms, IP protection regimes, and infrastructure in many emerging economies. These institutional voids present special challenges and obstacles both for indigenous firms looking to grow, innovate and diversify at home and overseas and also for foreign MNEs wishing to enter and succeed in emerging economy markets (Henisz, 2000; Hoskisson, Eden, Lau, \& Wright, 2000; Wright, Filatotchev, Hoskisson, \& Peng, 2005; Bowen, \& De Clercq, 2008; Dunning \& Lundan, 2008; Henisz \& Swaminathan, 2008; Peng, Wang, \& Jiang, 2008; Puffer, McCarthy, \& Boisot, 2010; Holmes, Miller, Hitt, \& Salmador, 2013; Meyer \& Peng, 2016). There is some evidence of convergence in institutional quality between (selected) emerging economies and the advanced economies (see the World Bank, Worldwide Governance Indicators), but this process is far from complete. Acemoglu and Robinson (2012) find that political institutions are less likely to change and to converge than economic institutions. This is because political elites may well support the reform of economic institutions, but have an incentive to maintain the 
political institutions that give them political power. More recently, national sovereignty is undermined by the rise of the GF. In a networked mode of organization of the world economy, the ability of any given state to exert control over a given node or the network as a whole is limited (Kobrin, 2018). Slow convergence in institutional quality is likely to be reflected in a slower convergence in the development of KI activities across countries than in fabrication activities.

\section{APPROACH}

We define the GF as the ensemble of all activities related to the production of manufacturing goods. These activities can take place within an MNE as well as in a single national firm. The firms engaged can be classified as manufacturing firms, but can also be classified outside manufacturing, such as business services or trading firms. The non-manufacturing firms contribute indirectly to the production of manufacturing goods through the provision of services/intermediate inputs in the production chain. This section introduces a set of indicators that allow one to track the income and productivity effects of participation in the GF for a particular country.

For ease of exposition, we need some basic notation. Let $L$ be the number of workers in the GF and let $P$ be the population of a country such that $L / P$ is an indicator of the scale of participation of a country in the GF. Note that $L$ does not refer to the total labor force, but only that part engaged in the GF of manufactured goods. Workers in the GF can be engaged in knowledge activities (indicated by superscript $K$ ) or fabrication (F) activities such that $L=L^{\mathrm{K}}+L^{\mathrm{F}}$. The share of knowledge workers $\left(L^{\mathrm{K}} / L\right)$ is then an indicator of specialization of a country in knowledge activities as opposed to fabrication activities. Each worker generates income such that the total income of a country generated in the GF is given by $Y=Y^{\mathrm{K}}+Y^{\mathrm{F}}$. The productivity of workers in a country that participate in the GF is given by $Y / L$, and similarly for knowledge workers $Y^{\mathrm{K}} / L^{\mathrm{K}}$ and fabrication workers $Y^{\mathrm{F}} / L^{\mathrm{F}}$.

Using these definitions, we can provide a simple, yet insightful, decomposition of GF income of a country per head of the population as follows:

$$
\frac{Y}{P}=\left[\frac{L}{P}\right] \times\left[\frac{L^{\mathrm{K}}}{L} \times \frac{Y^{\mathrm{K}}}{L^{\mathrm{K}}}+\left(1-\frac{L^{\mathrm{K}}}{L}\right) \times \frac{Y^{\mathrm{F}}}{L^{\mathrm{F}}}\right] .
$$

GF income of a country relates positively to the scale of participation in the GF $(L / P)$, its productivity levels in the two activities $\left(Y^{\mathrm{K}} / L^{\mathrm{K}}\right.$ and $\left.Y^{\mathrm{F}} / L^{\mathrm{F}}\right)$, and the weight of knowledge activities $\left(L^{\mathrm{K}} / L\right)$.

The framework is useful in better understanding convergence patterns in the global economy and the role of GF dynamics. 'Convergence' is a statistical concept in the literature on economic growth that refers to a process of narrowing income gaps across a set of countries (Baumol, 1986). The framework highlights different types of convergence: convergence in GF income per capita, which depends on the scale of activities in the GF and convergence in the productivity of these activities. To trace convergence, we will express the level of a country relative to the world frontier. In particular, we will track the degree of convergence between AMEs and EEs. We group Australia, Canada, Japan, South Korea, Taiwan, the United States, and the 15 pre-2004 members of the European Union in one group (the AMEs) and place all other countries, including the BRIC and Eastern European countries, in the world in the other group (EEs). Roughly speaking, this can be viewed as a comparison of the high-income countries of the world with other countries that play an active role in international trade (Hanson, 2012; Timmer, Erumban, Los, Stehrer, \& de Vries, 2014; Baldwin, 2016). ${ }^{5}$

We will trace the following relative measures:

Income ratio (GF income per head of population) :

$$
:\left(\frac{Y_{\mathrm{EE}}}{P_{\mathrm{EE}}}\right) /\left(\frac{Y_{\mathrm{AME}}}{P_{\mathrm{AME}}}\right)
$$

Scale ratio (GF workers per head of population) :

$\left(\frac{L_{\mathrm{EE}}}{P_{\mathrm{EE}}}\right) /\left(\frac{L_{\mathrm{AME}}}{P_{\mathrm{AME}}}\right)$

Productivity ratio (GF income per GF worker) :

$$
\left(\frac{Y_{\mathrm{EE}}}{L_{\mathrm{EE}}}\right) /\left(\frac{Y_{\mathrm{AME}}}{L_{\mathrm{AME}}}\right)
$$

Convergence in GF income per head is highly relevant from a welfare perspective. It is the contribution of GF participation to GDP per capita in a country. Keeping all other elements constant, GF income convergence can be accomplished by a country through increasing the scale of GF activities. Alternatively, productivity convergence in one (or both) of the activities will lead to GF income 
convergence. Finally, GF income convergence can be driven by specialization of the country in the more productive KI activities. We will quantify each of the drivers of GF income convergence in the next section. Each element of the framework has a clear interpretation and can be fruitfully linked to specific policy areas. For example, the participation in the GF will depend among others on the general trade and investment openness of a country, while specialization in knowledge activities will depend in part on the sophistication of a country's system of innovation. Productivity growth in fabrication activities can be stimulated by targeted industrial policies to advance product and process innovations, but may also exhibit patterns of unconditional convergence (Rodrik, 2012). This will be discussed in-depth in the policy section of this paper.

We measure GF income through empirical identification of the location and income of workers in the GF of final manufacturing goods. This approach can be seen as the macro-economic equivalent of the 'forensic' case-study approach taken by Dedrick, Kraemer, and Linden (2010). They studied the distribution of income and jobs in the production of the (by now obsolete) Apple iPod, circa 2006. The production process of the iPod is exemplary for the unbundling of production processes with intricate regional production networks feeding into each other. It was assembled in China from more than 100 components and parts sourced from around the world. So-called "teardown" reports provided technical information on the inputs used in the assembled product (such as the hard-disk drive, display and memory) as well as their market prices. This allowed the authors to trace the value captured by activities from the various participants in the chain beyond Apple, such as Broadcom (delivering microchips), Toshiba (hard disk) and Samsung (memory chips). Over 41,000 jobs worldwide were associated with the iPod global production network. A staggering $98 \%$ of the fabrication jobs were located in China and elsewhere in Asia, as almost all production had been offshored from the United States. Meanwhile, 65\% of the (much higher-remunerated) engineering and other professional jobs remained in the United States. The result was that almost three-quarters of the labor income generated in the Apple iPod global production network was estimated to accrue to US workers, with the Chinese workers capturing less than
2.5\% (Linden, Dedrick, \& Kraemer, 2011). Dedrick et al. (2010) provide similar decompositions for some other high-end electronic products such as notebooks; see also Ali-Yrkkö, Rouvinen, Seppälä, and Ylä-Anttila (2011) for a study of mobile phones. Kaplan and Kaplinsky (1999) provided a seminal contribution on South African peaches.

Such product-level studies have been invaluable, but do not give a sense of the generalizability of the phenomenon. This paper provides a global overview of GF incomes over the past three decades. We follow the method by Los, Timmer, and de Vries (2015) and extend it to account for labor income from fabrication and KI activities (see Appendix A for a brief mathematical exposition of the method). In short, we proceed in two steps. First, we trace, for a given good, the value that is added by any industry (in any country) in the world using information from the so-called global input-output tables. These are the counterparts to the technical teardown reports used in product-case studies. Second, we add information on the type of workers involved in each industry-country and their incomes, distinguishing between workers with occupations involved in fabrication and those involved in KI activities. This allows us to trace income for fabrication and KI activities earned anywhere in the world in the production of particular goods (e.g., textiles, or electronics). An illustration of our GF decomposition methodology is provided in Figure 1. It depicts a combination of a modular structure (a "spider") with sequential processes ("snakes"). This is for illustration only as our measure of GF income can be calculated for any constellation of the network and is not restricted to this particular form. Figure 1 refers to a simplified world economy consisting of three countries and depicts the production process of a good for which the last stage of production takes place in country A (say a Porsche finalized in Leipzig, Germany). ${ }^{6}$ To produce it, KI and fabrication activities are carried out by workers in country A. In addition, intermediate inputs are needed, some of which are produced within the country itself. Other intermediates are sourced from country B. To produce one of these intermediates, country B uses domestic workers and intermediate inputs produced in country C. Based on information of the size of the various production linkages and 


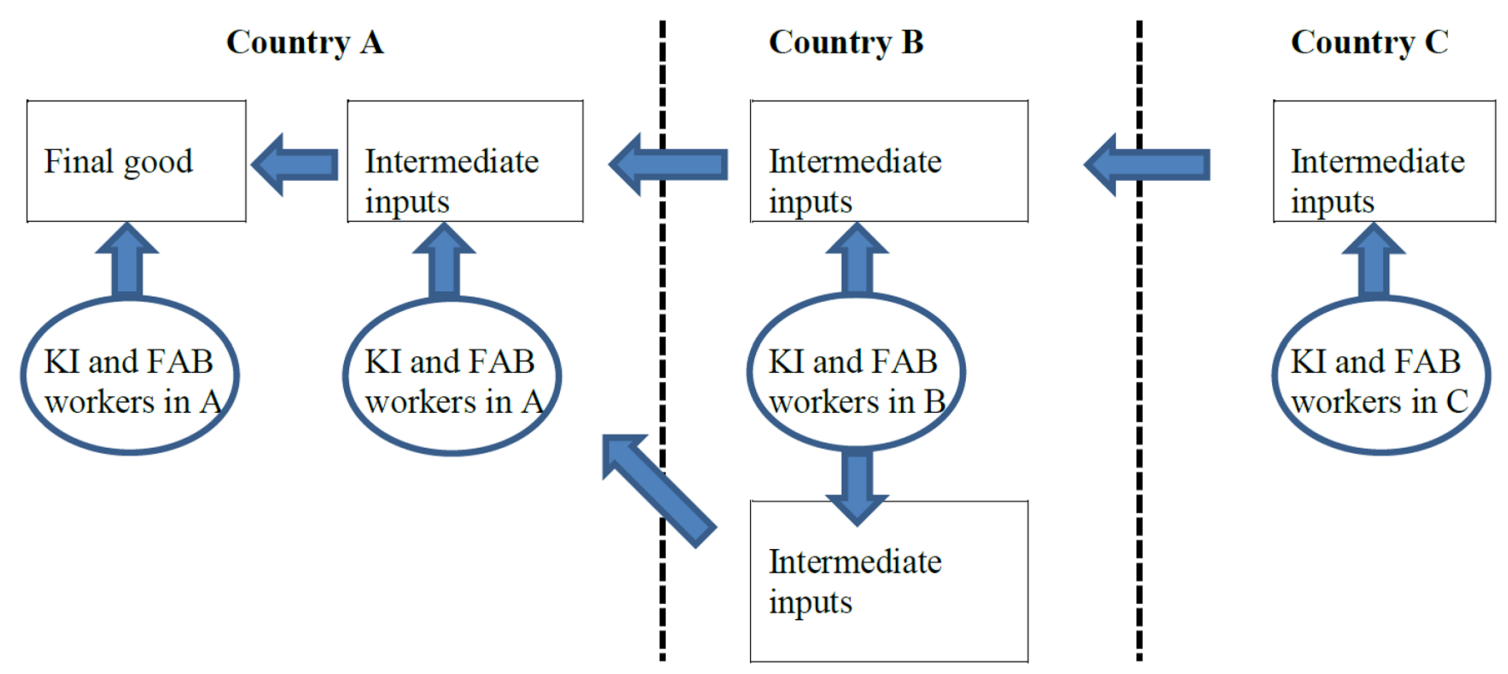

Figure 1 Stylized representation of a global factory. This figure depicts a combination of a modular structure (a "spider") with sequential processes ("snakes"). Our measure of global factory income can be calculated for any constellation of the network and is not restricted to this particular form.

the labor incomes of the workers, the contributions of $\mathrm{KI}$ and fabrication activities in this GF by countries $\mathrm{A}, \mathrm{B}$, and $\mathrm{C}$ can be calculated.

\section{DATA}

This section outlines new data to implement the framework introduced above. Basically, we combine information from two datasets to measure the location and type of incomes in the GF. The first dataset we use is the World Input-Output Database (WIOD). The WIOD provides global input-output tables that can be regarded as a set of national input-output tables connected to each other by bilateral international trade flows. They provide comprehensive summaries of all transactions in the global economy between industries and final users of goods and services across countries in a given year. In particular, the tables contain data on intermediate products that are used in the production of goods and services. These intermediates are traded within as well as across countries. The technical details are described in Dietzenbacher et al. (2013) and Timmer et al. (2015) and not repeated here. ${ }^{7}$ A major advantage of using the WIOD dataset in our analysis is that it is constructed under the conventions of the internationally agreed System of National Accounts (SNA) such that value added and income concepts align closely with the measurement of official macro-economic statistics such as GDP, value added and labor income. We follow the conventions of the SNA version 2008 as described in European Commission et al. (2009). This maximizes comparability of statistics over time as well as across countries. The WIOD covers 40 economies, together with an estimate for the "Rest of the World" which includes all other countries. The countries distinguished are the 27 EU countries (per January 2007) and 13 other major advanced and emerging economies, namely Australia, Brazil, Canada, China, India, Indonesia, Japan, Mexico, Russia, South Korea, Taiwan, Turkey and the United States. Together, these countries accounted for over $85 \%$ of world GDP in 2011. A limitation is that many developing countries in Latin America and Sub-Saharan Africa are not separately distinguished but combined in the "Rest of the World" group in the global inputoutput tables. However, these countries harbor only a minor share of activities in GFs of goods. ${ }^{8}$

The WIOD provides data in current US dollars based on exchange rate conversion of data in national currencies. It is well known that exchange rates do not fully reflect the cross-country differences in consumption prices which contain a large share of non-tradable services. ${ }^{9}$ To compare real GF income across countries, we report the GF income for each country at purchasing power parity (PPP) in constant 2011 prices. We use the price levels of output-side real GDP relative to the USA from the Penn World Tables, version 9.0 (Feenstra, Inklaar, \& Timmer, 2015).

Our second database is the Occupations Database introduced in Reijnders \& de Vries (2018) and 
Timmer et al. (2019). It has been updated to 2014 for the purpose of this analysis. It contains information on the occupations of workers based on representative survey and census data collected at the level of individuals by national statistical offices such as the Current Population Census and the annual American Community Surveys for the United States, European Union Labour Force Surveys, and data from the China Population Censuses and the China Household Income Project. The country coverage, industry classification and time span of these data tally with the WIOD and allow us to measure the occupational employment and GF income in global value chains. Appendix B contains a list of the main sources of data for each country, as well as a more detailed discussion of the harmonization approach.

The main distinction in our analysis is between $\mathrm{KI}$ and fabrication activities. We define fabrication activities as those activities carried out by workers with occupations involved in the physical transformation process. Example occupations are machine operators and assemblers. We define KI activities as activities that are carried out by workers involved in a wide range of pre-fabrication activities (conceptualization, R\&D, design, engineering, and specification development) as well as post-fabrication activities (marketing, branding and distribution). Workers involved in KI activities are employed in manufacturing and services industries. The allocation of workers into KI and fabrication activities is exclusive (each worker features only in one set) and exhaustive (each worker is allocated to a set). Appendix $C$ provides details of the two sets of workers and their descriptions, as well as exemplars of occupational categories.

\section{CATCHING-UP IN THE GLOBAL FACTORY}

In this section, we examine key trends in income from fabrication and KI activities in the GF. Following the convergence framework, responses can be characterized along three dimensions: scale, productivity and specialization. We will first reduce dimensionality of the data to facilitate the exposition and focus on differences in specialization across countries and changes in GF income.

Table 1 provides detailed information on changes in real GF incomes for each of the 40 countries in our dataset, ranked according to growth. China and India stand out, not only for the size of activities carried out in their economies but also for their outstanding growth rates, more than tripling (India) or even quadrupling (China) real GF income over the period 1995-2014 (see first three columns of Table 1). Also, Brazil and Turkey more than doubled their real GF incomes, alongside a handful of smaller economies (Czech Republic, Latvia and Slovakia). On the other hand, real GF incomes declined in some major AMEs including Italy, the United Kingdom, the United States and, in particular, Japan during this period. This is not true for most other AMEs, however, as shown, for example, by Germany and South Korea, which managed to increase real GF income by $48 \%$ and $78 \%$, respectively. This is because the expansion of the world economy has been associated with a larger demand for manufacturing goods as a new global middle class emerged which allowed for increased GF incomes in EEs without necessarily crowding out incomes in AMEs.

Countries varied not only in the growth of real GF income but also in the type of activities carried out. This is illustrated by the share of KI activities in overall GF income shown in the last columns of Table 1 . The results show a stark pattern of specialization in the world economy over the period 1995-2014. This pattern is consistent with the discussion of the division of labor in the literature review.

A stylized fact emerging from this table is that EEs are less specialized in KI activities than AMEs. Yet, in many EEs, there is a rapid decline in the share of fabrication activities. This is mainly because of the massive growth of fabrication activities in China, effectively driving out major competitors of fabrication activities in the world market. Facilitated by its accession to the World Trade Organization in 2001, China benefited from the rapid international fragmentation of fabrication and quickly took part in globally-integrated production networks (Baldwin, 2016). It should be noted that KI activities in China grew even faster than fabrication activities, as the KI share of overall Chinese GF income even increased (from 37\% to 40\%). However, in most other countries, the share of KI activities grew faster such that in 2014 China still has a major share of fabrication activities relative to other countries. India on the other hand had already specialized in KI-activities by 1995, and remained so in 2014: 70\% of GF income is generated in KI activities as opposed to $40 \%$ in China. Strong changes in specialization are recorded for Japan and the United States as the share of KI activities in overall GF income increased rapidly. At a closer look, it appears that real income from KI activities 
Table 1 GF income and KI specialization in the global factory

\begin{tabular}{|c|c|c|c|c|c|c|}
\hline \multirow[t]{2}{*}{ Country } & \multicolumn{3}{|c|}{ Real GF income } & \multicolumn{3}{|c|}{$\mathrm{KI}$ income as \% of GF income } \\
\hline & 1995 & 2014 & Change & $1995(\%)$ & $2014(\%)$ & Change (\%) \\
\hline China & 691,226 & $2,706,487$ & 3.92 & 37 & 40 & 3 \\
\hline India & 212,235 & 731,543 & 3.45 & 65 & 70 & 5 \\
\hline Czech Republic & 18,077 & 41,646 & 2.30 & 52 & 64 & 12 \\
\hline Turkey & 60,571 & 137,659 & 2.27 & 48 & 57 & 9 \\
\hline Brazil & 151,737 & 332,453 & 2.19 & 48 & 60 & 12 \\
\hline Latvia & 1,578 & 3,440 & 2.18 & 52 & 69 & 17 \\
\hline Slovakia & 7,082 & 14,676 & 2.07 & 53 & 63 & 10 \\
\hline Romania & 22,884 & 44,616 & 1.95 & 47 & 50 & 3 \\
\hline Russian Federation & 178,941 & 321,908 & 1.80 & 64 & 66 & 2 \\
\hline South Korea & 141,278 & 251,982 & 1.78 & 64 & 69 & 5 \\
\hline Indonesia & 142,968 & 249,038 & 1.74 & 76 & 71 & -5 \\
\hline Poland & 61,957 & 106,613 & 1.72 & 46 & 57 & 11 \\
\hline Luxembourg & 1,596 & 2,531 & 1.59 & 68 & 84 & 16 \\
\hline Hungary & 16,194 & 24,590 & 1.52 & 50 & 59 & 9 \\
\hline Estonia & 1,851 & 2,797 & 1.51 & 56 & 61 & 5 \\
\hline Taiwan & 86,555 & 128,805 & 1.49 & 55 & 62 & 7 \\
\hline Germany & 370,566 & 548,565 & 1.48 & 63 & 71 & 8 \\
\hline Ireland & 11,691 & 16,923 & 1.45 & 61 & 70 & 9 \\
\hline Austria & 29,921 & 42,926 & 1.43 & 52 & 67 & 15 \\
\hline the Netherlands & 57,388 & 81,751 & 1.42 & 71 & 79 & 8 \\
\hline Mexico & 70,586 & 96,578 & 1.37 & 47 & 51 & 4 \\
\hline Denmark & 15,943 & 21,312 & 1.34 & 60 & 71 & 11 \\
\hline France & 162,239 & 216,638 & 1.34 & 62 & 74 & 12 \\
\hline Sweden & 25,802 & 34,171 & 1.32 & 62 & 69 & 7 \\
\hline Canada & 91,573 & 114,848 & 1.25 & 54 & 58 & 4 \\
\hline Spain & 98,663 & 120,994 & 1.23 & 57 & 69 & 12 \\
\hline Slovenia & 6,269 & 7,432 & 1.19 & 50 & 62 & 12 \\
\hline Australia & 49,909 & 56,551 & 1.13 & 62 & 71 & 9 \\
\hline Greece & 17,427 & 19,656 & 1.13 & 57 & 70 & 13 \\
\hline Portugal & 21,610 & 24,366 & 1.13 & 56 & 63 & 7 \\
\hline Belgium & 38,128 & 42,576 & 1.12 & 65 & 75 & 10 \\
\hline Finland & 17,077 & 19,039 & 1.11 & 60 & 68 & 8 \\
\hline Bulgaria & 14,788 & 16,216 & 1.10 & 54 & 60 & 6 \\
\hline Italy & 231,650 & 223,869 & 0.97 & 66 & 67 & 1 \\
\hline United States & $1,040,279$ & 980,516 & 0.94 & 51 & 69 & 18 \\
\hline United Kingdom & 177,170 & 164,471 & 0.93 & 68 & 74 & 6 \\
\hline Cyprus & 1,177 & 1,081 & 0.92 & 52 & 75 & 23 \\
\hline Japan & 513,159 & 452,599 & 0.88 & 41 & 53 & 12 \\
\hline Malta & 936 & 713 & 0.76 & 54 & 70 & 16 \\
\hline Lithuania & 11,989 & 6,602 & 0.55 & 54 & 59 & 5 \\
\hline
\end{tabular}

GF and $\mathrm{KI}$ incomes are calculated as described in the main text. The change in GF income is measured as GF income in 2014 divided by the level in 1995. The change in KI specialization is measured as the share in 2014 minus the share in 1995 . All income values are expressed in US\$ at constant 2011 PPPs.

remained relatively constant over time, while income from fabrication activities rapidly declined. This clearly illustrates that trends in the GF have been relatively benign for knowledge workers in these countries as demand for their work did not decline in absolute terms, and increased relative to demand for fabrication work. ${ }^{10}$
Figure 3 summarizes the detailed country-level information, plotting country experiences along the two dimensions: change in GF income on the horizontal axis (measured as GF income in 2014 divided by level in 1995) and change in specialization on the vertical axis (KI income share for 2014 minus the share in 1995). Countries on the east side of the graph experienced rapid growth in GF 


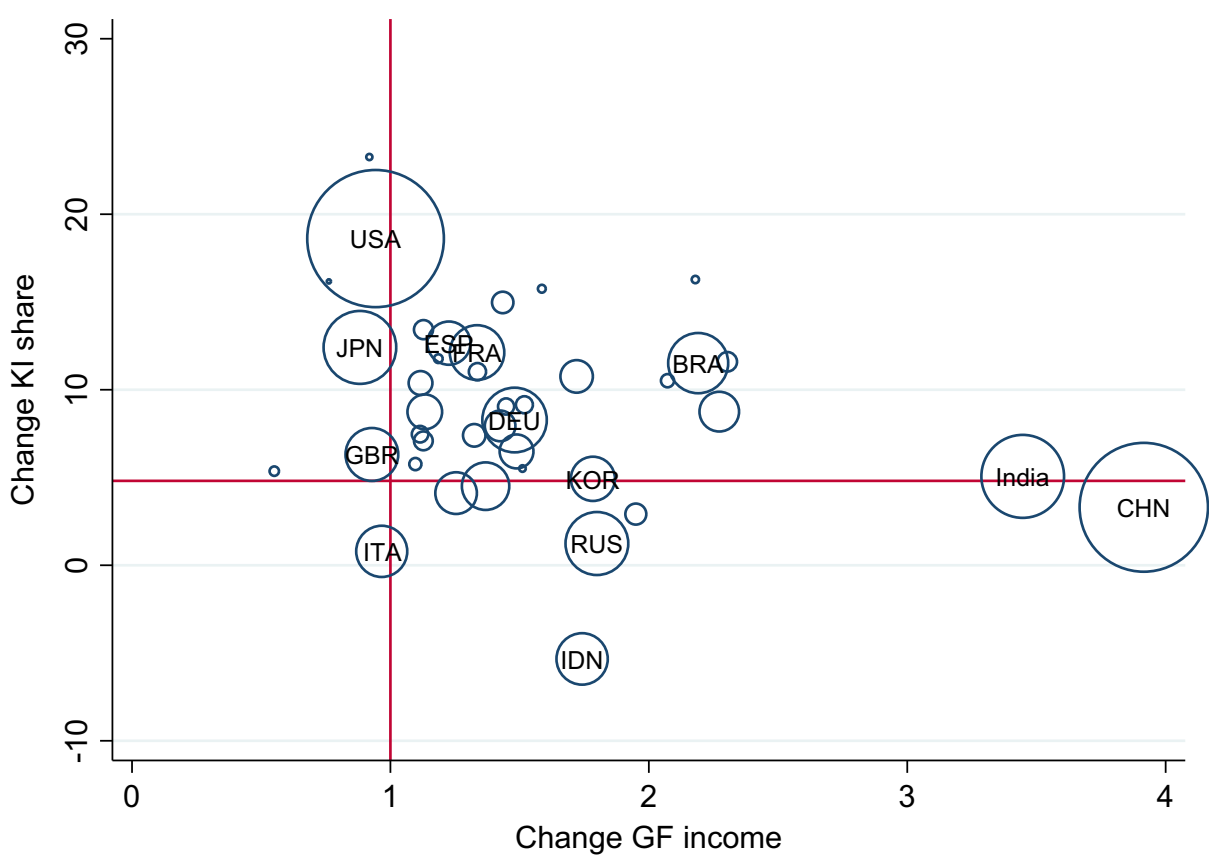

Figure 2 Change in GF income and KI specialization, by country. The change in GF income between 1995 and 2014 is on the horizontal axis. The change in KI share is on the vertical axis, multiplied by 100 Data taken from Table 1. Bubbles reflect country's size of GDP (at PPP) in 2011.

income, while countries on the north side experienced rapid KI specialization in the GF. Figure 2 shows China and India are examples of EEs where the size of activities exploded providing massive opportunities for gainful employment of previously underutilized workers, lifting them out of poverty. On the other extreme, Japan and the United States are AMEs where the size of GF activities declined, in particular of fabrication activities. This was one of the drivers of polarization of the labor markets and decreasing relative wages for less skilled workers carrying out routine fabrication jobs. France and Germany are AMEs which succeeded in benefiting from the growing global consumer market, increasing the size of activities not only for skilled workers that carry out KI activities but also for less skilled workers carrying out fabrication activities. They were less affected by the China shock than AngloSaxon countries.

For analyzing convergence, we start with income from all activities in the GF, without distinguishing between different types of activities. Figure 3 shows real GF income per capita in EEs as a percentage of that in AMEs for the period 1995-2014. ${ }^{11}$ Two observations stand out. First, a rapid catch-up of EEs vis-a-vis AMEs since the early 2000s. This process continued through the 2010s, albeit slowing down at the end of the 2000s. The growth rate of real GF income over the period 2008-2014 was $-0.2 \%$ for AMEs and $6.9 \%$ for EEs. ${ }^{12}$ Second, by 2014, a sizeable gap remained as the level of GF income per head in EEs reached $37 \%$ of the level in AMEs. This is because rapid catching-up took place from a low level, around $15 \%$ in the 1990s. ${ }^{13}$ We conclude that, in 2014, emerging economies still only generated less than half the income per capita of advanced market economies in the GF. This might be surprising in the light of writings in the popular press which emphasize the rapid growth of manufacturing activities in EEs. Yet, this unexpected result can be explained once we apply our framework and distinguish between fabrication and KI activities, as well as between scale and productivity convergence.

The overall convergence trend for all activities in the GF hides an important difference in convergence rates for particular sets of activities. Figure 4 shows the relative ratios of GF income from fabrication and KI activities. EEs have been catching-up in both activities, but the pace at which EEs were catching-up was much higher in fabrication activities. In 2014, GF income per capita in EEs from fabrication stood at $56.4 \%$ of levels in AMEs, but at only $28.1 \%$ for KI activities.

Figure 4 also suggests a difference in the timing of the convergence process, which seems to have 


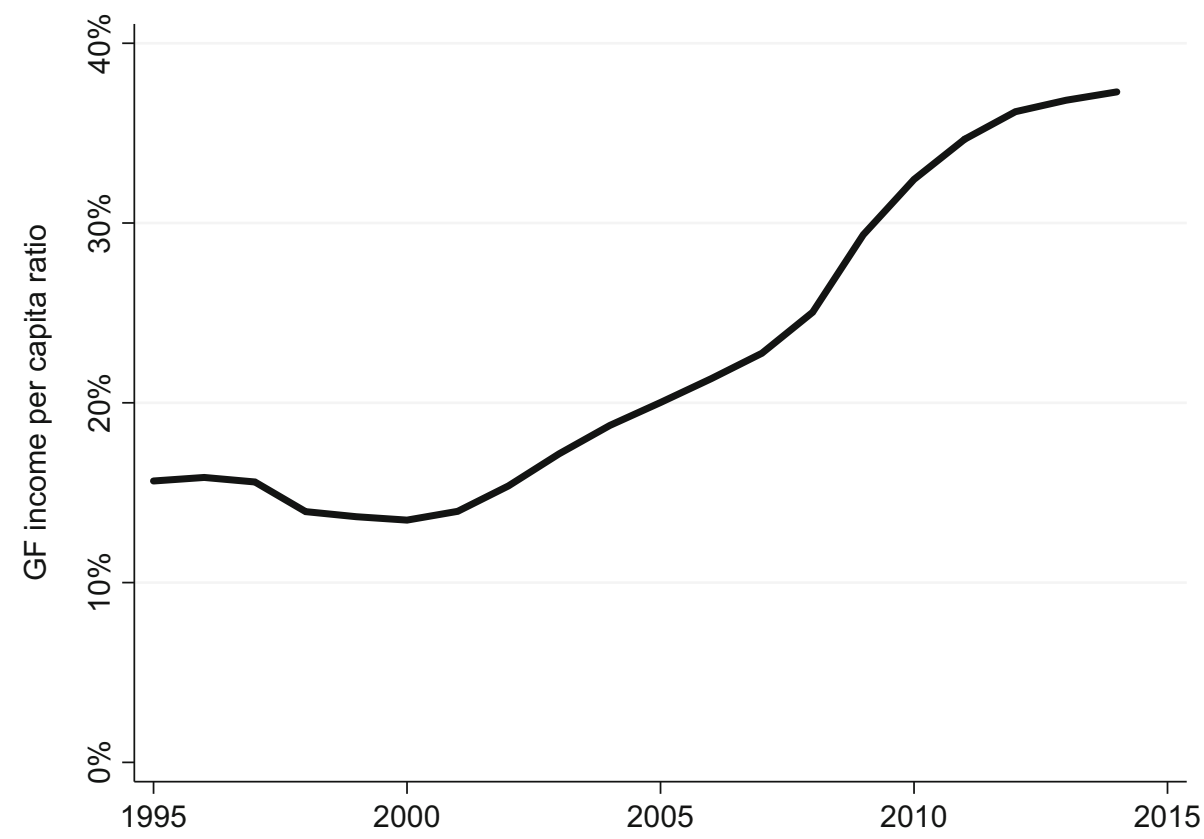

Figure 3 Global factory income per head of the population (EEs relative to AMEs). Calculated as income earned in the global factory of goods, expressed per head of the population and at 2011 constant PPPs. Level in emerging economies relative to advanced market economies, see Eq. (2a). For country groupings, see footnote 5. Authors' calculations based on the World Input-Output Database and the Occupations Database.

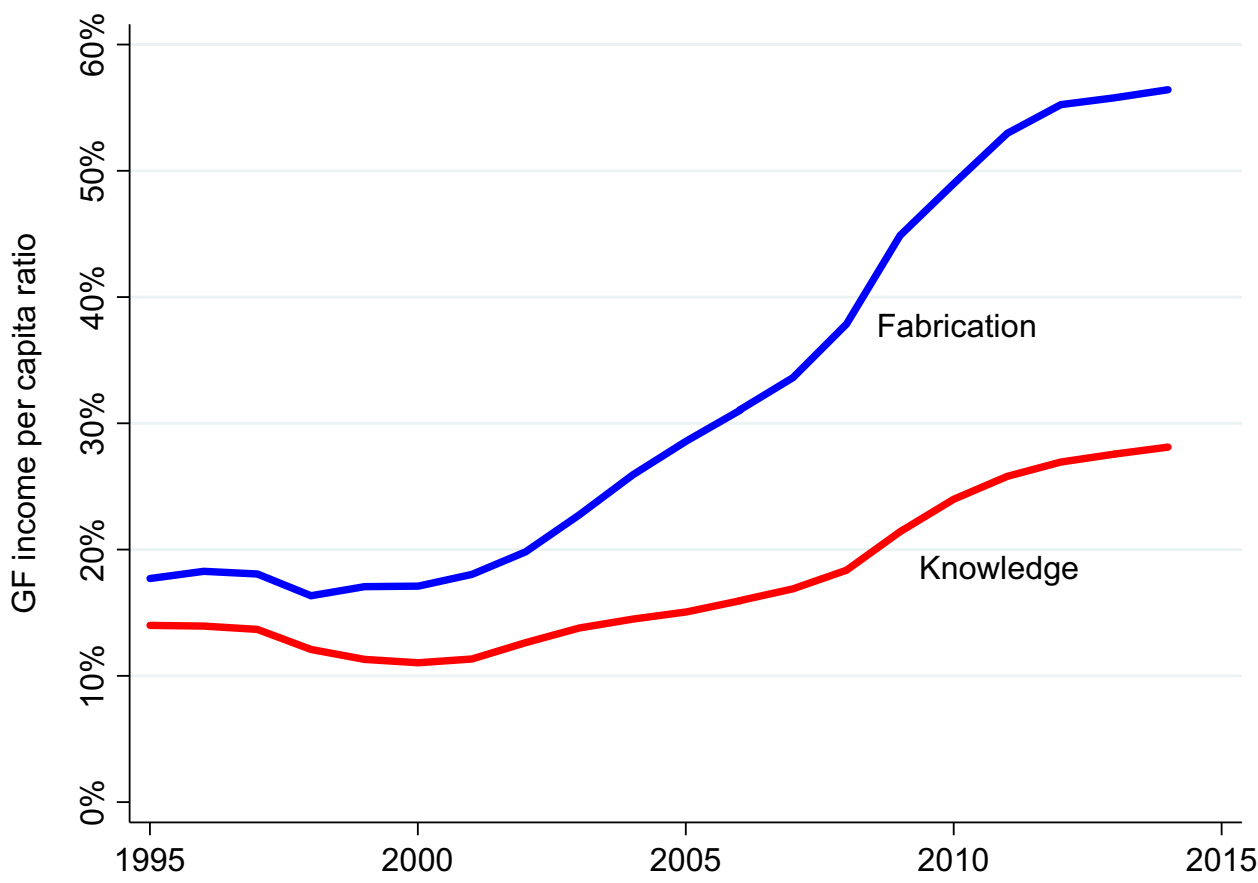

Figure 4 Global factory income per head of the population (by activity). Method and sources as for Fig. 2 but calculated separately for incomes from knowledge-intensive and fabrication activities.

started first for fabrication activities. GF income from KI activities started to converge only around the mid-2000s. This supports theories related to the sequential nature of offshoring, first in fabrication and later in KI activities, as discussed in the "Theoretical Background" section. Interestingly, 


\section{2}
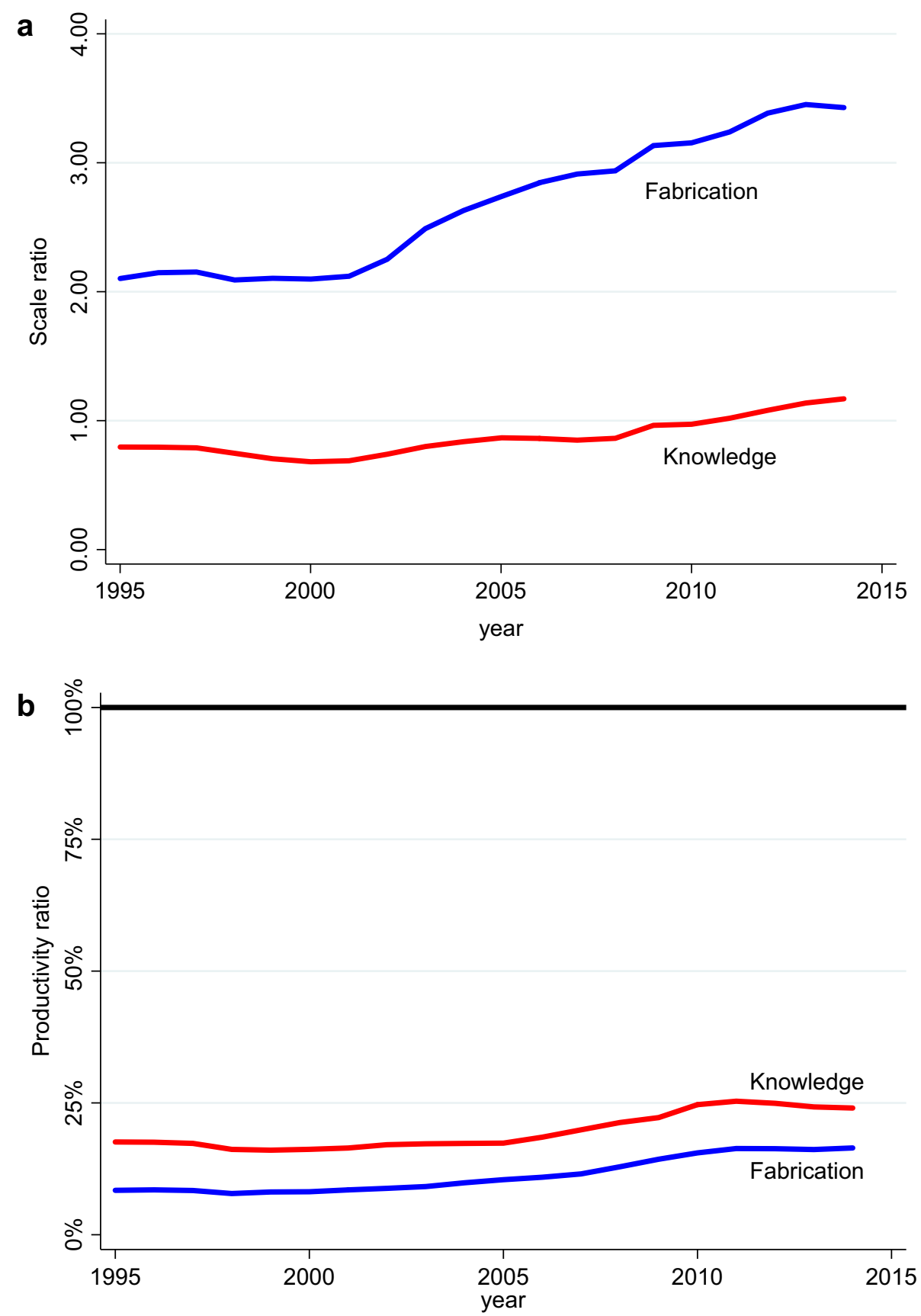

Figure 5 Scale and productivity in the global factory (EEs relative to AMEs). a Scale (global factory workers as a share of the population). b Productivity (income per worker in the global factory). The scale ratio is the share of workers in emerging economies involved in fabrication or KI divided by population relative to that share in advanced market economies, see Eq. (2b). The productivity ratio is income per worker in emerging economies for fabrication or KI relative to income per worker in that activity in advanced market economies, see Eq. (2c). Red line for knowledge-intensive activities, blue line for fabrication activities. Authors' calculations based on the World Input-Output Database and the Occupations Database.

the timing that we observe here coincides almost exactly with Dossani \& Kenney (2007: 777), who argue that "although there is little empirical evidence, there is anecdotal evidence from the popular press that since 2004, there has been a widespread acceleration in offshoring more skilled (and credentialed) positions in R\&D, design, and sophisticated mathematics-based financial and actuarial 


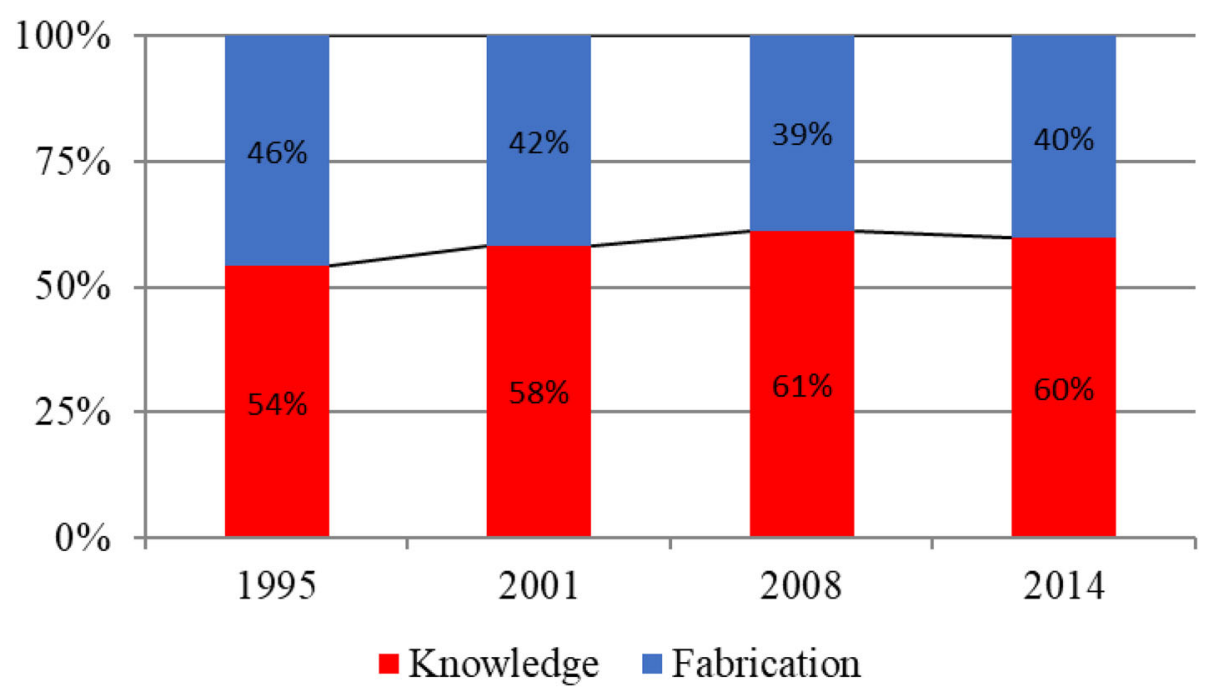

Figure 6 The increasing importance of knowledge intensive activities in the global factory. Value-added share from knowledge-intensive and fabrication activities in global factory of goods. Authors' calculations based on the World Input-Output Database and the Occupations Database.

analysis requiring post-graduate degrees to name only a few." The increasing value of KI activities in emerging countries also supports the theory that MNEs set up marketing, design and other centers to be able to adapt products to the needs and tastes of new consumer markets (Castellani \& Pieri, 2013). It highlights the need to investigate substitutability and complementarity of fabrication and KI activities in home and foreign markets (Belderbos, Lokshin, \& Sadowski, 2015).

Where does the much faster convergence in fabrication activities come from? Figure 5 examines the role of increases in scale and productivity. Scale convergence (the share of GF workers in the total population), measured using Eq. $2 \mathrm{~b}$, is plotted in panel (a). Employment in fabrication activities was growing at $0.9 \%$ in EEs (over the period 20082014), while declining with $2.1 \%$ in AMEs. As a result, EEs forged ahead in scale, rising from double the level in AMEs in 1995 to more than three times in 2014. This change is clearly visible in the shifting in locations of manufacturing plants around the globe, and has given rise to proclamations of "manufacturing decline" in the West, although this leaves out consideration of other important (KI) activities in the GF. Convergence in the scale of KI activities was much slower and the relative level in 2014 was a little higher than the level in 1995 (1.17 in 2014 compared to 0.80 in 1995). The larger share of workers from EEs participating in the fabrication activities in the GF is partly a reflection of the stronger orientation towards the provision of non-traded services in AMEs.
Productivity (GF income per worker) convergence, measured using Eq. 2c, is plotted in panel (b). Productivity levels in EEs in fabrication were low in 1995, at about $8 \%$ of the level of productivity in AMEs, doubling over the period 1995-2014 to about $16 \%$. The low relative productivity level relates to MNEs locating the least productive activities in developing countries, while keeping capitalintensive and often automated fabricated activities in advanced countries. Convergence in productivity of KI activities was consequently slower, with relative levels rising by one-third: from $18 \%$ in 1995 to $24 \%$ in 2014.

We conclude that the convergence process in the $\mathrm{GF}$ is far from complete. There has been a very strong increase in the scale of fabrication activities carried out by EEs, but much less so in the scale of KI activities. Moreover, relative productivity levels in EEs are still well below the productivity levels in AMEs for both types of activities. As a result, GF income per head of the population in the EEs is still well below the level in AMEs that continue to specialize in high-productive KI activities.

Scale convergence in KI activities is relevant for the economic future of EEs in the view of the "deepening smile curve" hypothesis. The wellknown "smile curve" of global value chains first formulated by Stan Shih of Acer in 1992 (Mudambi, 2008; Park et al., 2013) states that fabrication activities typically have the lowest remuneration relative to other activities in the chain, and that this gap is increasing over time. The hypothesis posits that, with the opening up of cheap labor 

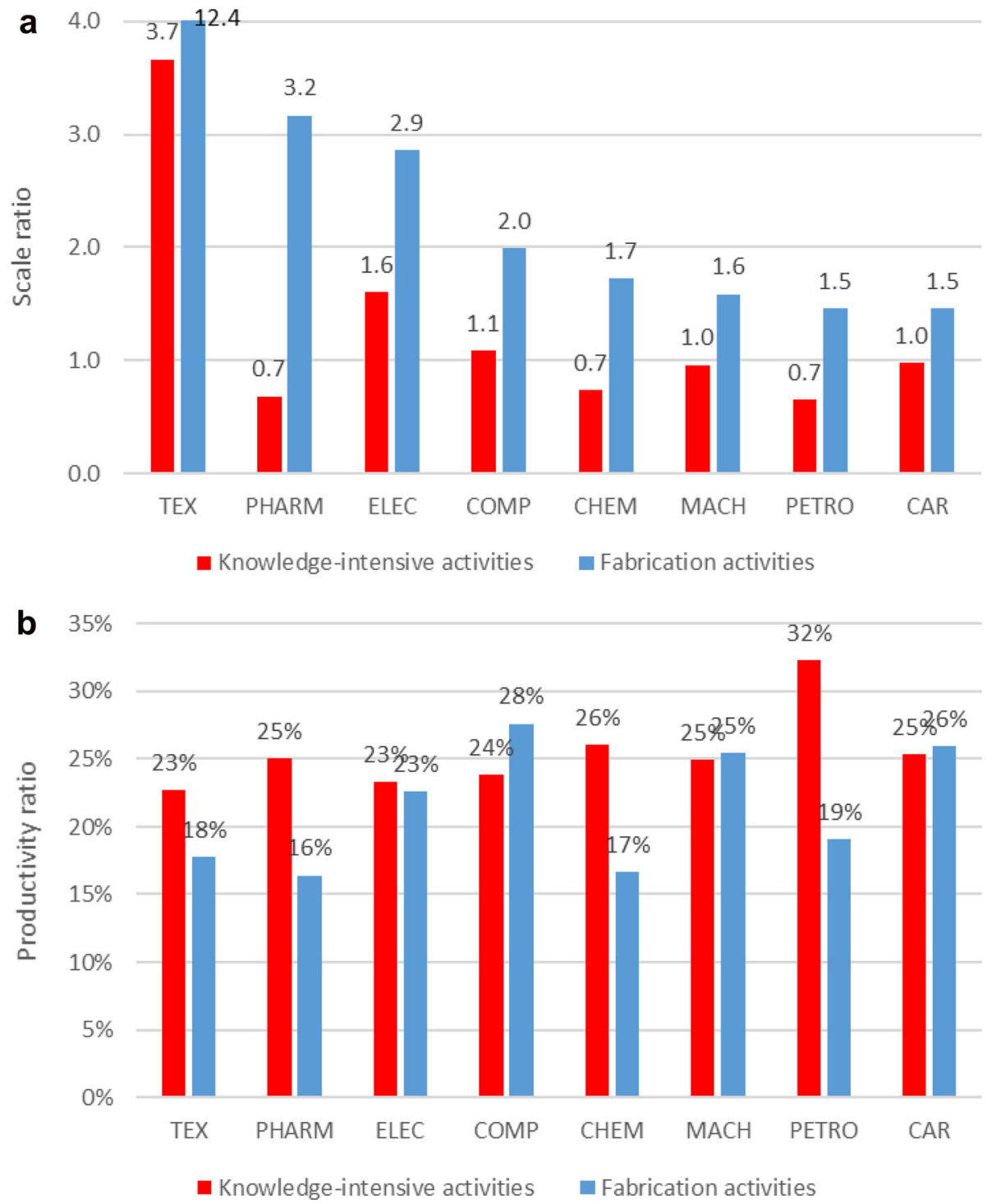

Figure 7 Scale and productivity levels (EEs relative to AMEs) by product group, 2014. a Scale (employment per capita). b Productivity (GF income per worker). As for Figure 5 but for separate product groups. TEX textiles, wearing apparel and leather products, PHARM pharmaceutical products, ELEC electrical equipment, COMP computer, electronic and optical products, CHEM chemical products, MACH Manufacture of machinery and equipment, PETRO refined petroleum products, CAR motor vehicles and trailers.

locations in the world economy, the incomes generated in fabrication activities would decline relative to more KI pre- and post-fabrication activities. In addition, there has been a strong process of so-called "servicification of manufacturing" (Pilat et al., 2008; Crozet \& Millet, 2017). For example, Kelle (2013) found a large shift in German manufacturing firms toward services exports, not only producing, but also installing and maintaining machinery. Bernard and Fort (2015) document the rise of factoryless goods producers in the USA.
These firms design the goods they sell and coordinate production networks, yet are not actually engaged in fabrication activities. Fontagné and Harrison (2017) discuss many more examples.

We present evidence for the deepening of the smile curve. Figure 6 shows the share of fabrication and KI activities in the overall GF income generated in the production of manufactured goods. It shows that income from KI activities has grown faster compared to fabrication activities and accounts for $60 \%$ or more of overall GF income since 2008 , up 
from $54 \%$ in 1995 . It is prima facie evidence of a deepening of the smile curve in which added value creation in upstream and downstream activities proceeds at a faster pace compared to fabrication activities. ${ }^{14}$ Future GF income convergence will therefore depend more and more on EE's ability to capture a larger share of KI activities in the production of goods.

So far, we have considered the global production of all manufactured goods together. Yet, it is likely that the speed of convergence differs across products. For example, KI activities in apparel are arguably easier to enter than pharmaceuticals if only because of the higher strategic importance of patents in the latter. More generally, one would expect slower catching-up in production processes that are highly dependent on intellectual property, such as patents and trademarks, or that are technologically advanced and require superior capabilities and reliance on tacit knowledge acquired through learning and experimenting. In Figure 7, we provide information on catching-up for eight major product groups. ${ }^{15}$ We present, for example, the GF income from electronic products. Be reminded that this is not the same as GF income generated in the electronics industry. This is because many firms in a wide range of sectors (manufacturing, mining, finance and business services, etc.) are involved in the GF of developing, designing, marketing, producing, transporting and selling electronic products.

Figure 7 shows scale (upper panel) and productivity (lower panel) in EEs relative to AMEs. This is similar to Figure 5, but now for separate product groups and only for the latest year for which we have data, which is 2014 . The products are ranked in declining order based on their relative scale ratio for fabrication activities. Our main finding at the aggregate level is reflected here: we find for all product groups that the scale gap in KI activities is (much) larger than in fabrication activities. This is strong evidence in favor of the technology stage hypothesis discussed in the "Theoretical Background" section. Productivity gaps are major in both activities, despite rapid catch-up in the 2000s.

In addition, we find interesting variation across products. Not surprisingly, the scale of activities of EEs in the GF for textiles (including textiles, wearing apparel and footwear) is a major outlier: the number of fabrication workers (per capita) in EEs is more than 12 times the level in AMEs. For KI activities, it stands at almost 4 times the level in AMEs, suggesting that many textile workers in EEs are also involved in pre- and post-fabrication activities of the global textile factory. A sizeable part of fabrication activities in pharma is in EEs (3.2 of AME level), yet it has the biggest gap in KI activities (0.7 of AME level). The wind turbine sector studied in Awate et al. (2012) and Awate \& Mudambi (2018) is part of machinery manufacturing. The level of disaggregation in the WIOD does not allow us to examine production and innovation capabilities solely in this sector. However, our results for the broader set of machinery products are consistent with those reported in Awate et al. (2012) with a relative low KI activity level. More generally, our findings at the product level consistently show strong convergence in the scale of fabrication activities. For all products, except textiles, we find that the GF income gap from KI activities is still formidable in 2014. We conclude that catching-up in the GF is, as yet, far from complete. Scale effects have been very strong in the carrying out of fabrication activities, but still incomplete in KI activities. Productivity levels in EEs are still well below those in AMEs in both types of activities.

\section{DISCUSSION}

In this paper, we have demonstrated that the convergence process in the GF is far from complete. There has been a very strong increase in the scale of fabrication activities carried out by EEs, but much less so in the scale of KI activities. Moreover, relative productivity levels in EEs are still well below those in AMEs for both types of activities. Our findings do not gainsay that there are many case-studies of successful MNEs in emerging economies that have been able to graduate. There is a substantial literature documenting cases of upgrading by individual firms in specific industries in emerging economies (e.g., Dossani \& Kenney 2007; Di Gregorio, Musteen, \& Thomas, 2009; Lewin, Massini, \& Peeters, 2009; Nieto \& Rodríguez, 2011; Castellani, Jiminez, \& Zanfei, 2013; Awate et al., 2015; Choksy, Sinkovics, \& Sinkovics, 2017; World Bank, 2017). Yet these are the exceptions and not the rule, hinting at the existence of major barriers to international technology diffusion and the development of indigenous innovation capabilities by EE firms. MNEs from the advanced economies are important players within the GF (Buckley \& Strange, 2015), and how they exercise their power and strategic control will have crucial implications for income distribution. Do MNEs organize their 
production networks to promote efficiency throughout the chain, and then allocate the resultant income equitably among the various participants (Kano, 2018)? If so, on what basis is it possible to determine an equitable allocation of income? Or do MNEs leverage the power asymmetries within their networks to select tractable partners, and to orchestrate the activities in such a way that the resultant income is distributed to their advantage (Strange \& Humphrey, 2019)? If so, what are the sources of the MNEs' power, and how may the MNEs guard against the dissipation of these rents over time (Denicolai, Strange, \& Zucchella, 2015; Reimann \& Ketchen, 2017)? Is the allocation of rewards fair or just (Palpacuer, 2008)? Further research is needed on the governance structure and the bargaining power of firms, as these are prime determinants of the distribution of income across the production network partners (Coff, 1999; Levy, 2008).

It is important to note that our analysis has focused on labor income. Yet a significant part of the growth of fabrication activities (and also KI activities) in emerging economies is funded by MNEs from the advanced economies; hence, some of the value created will accrue as capital income to the MNEs, notwithstanding where the activities are undertaken. Indeed, the available data suggest that net FDI flows to emerging economies are substantial, as are the income flows therefrom. Several studies report falls in the share of labor income and worsening of income inequality across the world (Alvaredo, Chancel, Piketty, Saez, \& Zucman, 2017; Dao, Das, Koczan, \& Lian, 2017), and the consequent 'anti-globalization' sentiments among the disadvantaged - or those who perceive disadvantages - from globalization (Rodrik, 2018b). Our own back-of-the-envelope estimates, based on FDI capital stock data from UNCTAD (and allocating capital income proportional to the share of foreign and domestic capital stock), suggest a substantial increase in the share of capital income accruing to foreign capital. In 1995, foreign capital captured slightly over $10 \%$ of the capital income generated globally in the GF, rising to almost $17 \%$ by 2014 . Such FDI income flows will dampen the convergence in labor incomes between the developed and the emerging economies as documented in this paper. Now, an increasing proportion of the capital income generated in the emerging economies in the future may be retained domestically either because indigenous MNEs and other firms are coming to the fore, or because the technical, managerial and marketing know-how transferred by developed economy MNEs has raised either directly or indirectly the productivity of local firms (Crespo \& Fountoura, 2007; Dunning \& Lundan, 2008; Turkina \& van Assche, 2018). On the other hand, there is abundant evidence of the increasing importance of intangible capital, such as intellectual property, brands, databases and supply systems (Haskel \& Westlake, 2018). Chen, Los, and Timmer (2018) provide some preliminary analysis of the importance of intangibles in the production network of manufactured goods, and report that the share of income accruing to intangible capital increased rapidly to more than $30 \%$ of final output value in 2014. This was almost double the returns to traditional tangible capital. Following the analysis in this paper, one would like to trace this to particular activities in the chain. The activity of workers can be easily described using their occupations, as shown in this paper. Yet, this is much more difficult for capital assets: for example, a computer can be used for fabrication as well as KI activities. Moreover, most intangibles are produced by knowledge workers such that there is an intertemporal link between labor and capital incomes. The unpacking of capital incomes into pure profits, depreciation allowances and normal rates of returns is needed to understand the role of intangibles in GF incomes.

Our final point concerns technology, which we have identified as a key driver of the convergence process. Technology is not homogeneous across industrial sectors, nor does it require an homogeneous set of capabilities, and it is constantly evolving. The technology frontier for any firm is thus not a fixed target, and new technologies bring new requirements for different labor skills. One particular instance is the widespread adoption of new digital technologies, and in particular the adoption of robotics and additive manufacturing. This will undermine the production cost advantages of many emerging economies, and may well lead to production being located closer to final consumption (Strange \& Zucchella, 2017). In time, this will lead to the reshoring to the advanced economies of many productive activities, even though the number of jobs reshored may be more modest. An illustrative contemporary example is provided by the footwear manufacturer, Nike, long cited and often criticized as an early proponent of offshoring labor-intensive activities to cheaper and less well-regulated locations in Asia (Mudambi \& Puck, 2016). Since 2015, Nike has been working 
with Flex, a high-tech manufacturing company better known for producing Lenovo servers and Fitbit activity trackers, to instil greater automation in the labor-intensive shoe manufacturing process (Bissell-Linsk, 2017). Flex's factory in Guadalajara, Mexico, has become one of Nike's most important supply facilities, responsible not just for an increasing share of the Nike's production but also for a string of innovations (e.g., laser-cutting and automated gluing) to be introduced across the rest of Nike's supply base. The shift to automation not only pushes down labor and raw material costs but also allows quicker delivery to the fashion-conscious final consumers. However, the automation may also lead to a lower need for the roughly 1 million production workers employed in Nike's subcontractors worldwide. Meanwhile, the deployment of these new digital technologies should result in KI activities becoming less location-bound and thus potentially more geographically dispersed (Mudambi \& Puck, 2016), putting the developmental emphasis of host counties ever more on the creation of appropriate skills and capabilities. Clearly, these new technologies will have a major impact on the distribution of incomes in the GF, but the timing and extent of this impact are conditional upon many other factors, not least political responses to the likely shifts in income and employment.

\section{POLICY IMPLICATIONS}

A major problem for policy-making of governments is that the GF cuts across the 'nexus' of foreign direct investment and trade policies (Buckley, 2018; Gereffi, 2019). Put otherwise, national, international and local policies do not address GF dynamics except partially. This study has shown that activities in the GF shifted dramatically across locations and types. It is a mistake to assume a uniform movement towards "convergence" of manufacturing productivity and scale between advanced and emerging country locations. We also cannot assume uniformity in technology diffusion across locations, depending on the type of technology. The fact that these activities take place both within MNEs as well as through market transactions through contracts further complicates policy formulation at all levels.

In general, it is safe to say that policies at all levels have to be flexible to accommodate the dynamics of global value chains. Our discussion above suggested that catch-up and convergence in the GF is highly conditional upon international technology diffusion and the development of indigenous innovation capabilities by domestic firms. These in turn depend upon firms developing and mastering the capabilities required for KI activities, and on governments both relaxing constraints on external technology acquisition and introducing necessary political and/or institutional changes. Convergence at an aggregate level will require the development and continual improvement of national innovation systems in poorer economies that embrace "national education systems, labor markets, financial markets, intellectual property rights, competition in product markets and welfare regimes" (Lundvall, 2007: 102). This development may be supported by the creation of clusters (Turkina \& Van Assche, 2018). Such measures are, however, far from costless (Bartels, Voss, Lederer, \& Bachtrog, 2012; Zanello, Fu, Mohnen, \& Ventresca, 2015) and, as argued above, partial at best.

The findings of this paper therefore represent a challenge to policy-making in the presence of the GF. We strongly believe that understanding "the facts on the ground" is a vital first step in rational policy-making. And we hope that this paper provides a stepping stone for further analysis of GF dynamics. In particular, for policymakers in AMEs, an important lesson is that the perceived threat of GVCs undermining their technological edge has been over-blown, but that at the same time policy should focus on ensuring they keep on investing in these higher value-added activities. For developing countries, our findings seem to imply that simply increasing the scale of KI activities is insufficient, as necessary improvements in productivity appear slow to materialize.

We have also argued the need for better information on the generation and division of rents in global value chains, which, in contrast to labor incomes, are much more difficult to trace and attribute to countries. We highlighted in particular the increasing importance of cross-border flows of intangible capital, such as intellectual property, brands and databases for value creation. Second, it appears that more general policies such as those on education, labor markets, intellectual property rights and the rule of law - are more important in the long run in attracting, retaining and upgrading relevant parts of the GF than are specific GF related policies, such as the establishment of Special Economic Zones (SEZs). Overall trade and investment openness of a country is a clear pre-condition for the needed 
catching-up in the scale of fabrication activities. However, enlarging the scale of KI activities will crucially depend on the sophistication of a country's system of innovation. A third consideration is the absolute necessity of international policy cooperation, as no one country can influence global production networks without repercussions for others. In general, it is safe to say that policies at all levels have to be flexible to accommodate the dynamics of production networks. Fourth, the control of the exercise of monopoly positions is as crucial in the international sphere as it is domestically, but international oligopolies are ferociously difficult to restrain, in particular when the use of intangible assets is the basis for rent-seeking. Distributional and welfare outcomes are influenced, if not determined, by rent-seeking and the global inequalities generated are of increasing concern.

Overall, this paper has posed a number of important policy dilemmas arising from imperfect convergence in the GF. The challenge is to further improve our understanding and then to agree on appropriate national and international policies.

\section{ACKNOWLEDGEMENTS}

We thank the editor, Ram Mudambi, two anonymous referees and participants at presentations at the Academy of International Business conferences in Bengaluru, India (2015), and Dubai, United Arab Emirates (2017) for stimulating comments and discussions. Timmer acknowledges financial support from the Dutch Science Foundation (NWO) (Grant Number 453-14-012).

\section{NOTES}

${ }^{1}$ The value chain conceptualizes the production of goods and services as a process involving a series of distinct value-creating activities (including production, marketing and sales, materials management, R\&D, technology development, human resources, IT, and firm architecture) (Gereffi, 2018). At each stage in the process, an intermediate good or service is produced which then becomes an input to the next stage of the process, until, in the final stage, the final product is sold to the end user/consumer. Some authors suggest that the 'chain' concept is not helpful as many intermediate products are used concomitantly rather than sequentially in the production process, and prefer to refer to production networks. Furthermore, many chains/networks involve activities being carried out in more than one country - these are typically referred to as global value chains (GVC) or global production networks (GPN). The emphasis in the GVC/GPN literature is typically on the geographical location of the value-creating activities, and on the linkages between them (Gereffi, 2019). A complementary perspective is provided by the GF literature where the emphasis is more on the governance (ownership and control) of the GVCs, on which activities are internalized within MNEs and which are externalized, and the implications for the capture of the value created within the GVCs (Buckley \& Strange, 2015).

${ }^{2}$ The previous phase of globalization, dating from the early 1800 s, had involved the progressive concentration of economic, political, cultural and military power in a few rich economies. Historians refer to this phase as the "Great Divergence"; see also Jones (2017).

${ }^{3} \mathrm{GDP}$ per capita at purchasing power parity (constant 2011 international \$).

${ }^{4}$ Labor productivity is commonly measured as value added, rather than income, per worker. We use income per worker as a proxy for the reasons outlined below, related to the difficulty in the attribution of capital income to countries.

${ }^{5}$ We consider the following as advanced economies: Australia, Austria, Belgium, Canada, Germany, Denmark, Spain, Finland, France, Greece, Ireland, Italy, Japan, South Korea, Luxembourg, the Netherlands, Portugal, Sweden, Taiwan, United Kongdom, and the United States, and the following as emerging economies: Bulgaria, Brazil, China, Cyprus, Czech Republic, Estonia, Hungary, India, Indonesia, Lithuania, Latvia, Mexico, Malta, Poland, Romania, Russia, Slovakia, Slovenia, and Turkey. Several transition economies are now highincome, but they were more accurately characterized as emerging during most of the period studied in this paper.

${ }^{6}$ It should be noted that this type of analysis does not depend on the production process being linear ("chain"), nor presumes that it is. It is equally valid in any network configuration that can be described by individual stages of production that are linked through trade. To stick with commonly used terms, we refer to all fragmented production processes as "chains", despite the linear connotation of this term. 
${ }^{7}$ The data are free and publicly available at https://www.wiod.org. Currently, WIOD is one of the most widely used databases to study the macroeconomic implications of global trade integration. The data are the outcome of a research project by a European research consortium consisting of eleven institutes. The WIOD project started in 2009 and the first international input-output tables were launched in 2012 (with annual data for the period 1995 to 2011), followed by a substantial update in 2016 (with data for 2000 to 2014). We calculate our measures for the latest data set and extrapolate backwards with the measures based on the earlier database to arrive at series for the long period 19952014.

${ }^{8}$ Baldwin (2016) focuses on China, Korea, India, Poland, Indonesia and Thailand, at times extended by other emerging economies like Brazil and Mexico. We cover all these countries, with the exception of Thailand.

${ }^{9}$ We use so-called constant Purchasing Power Parities (PPPs) for the year 2011 to adjust for differences in price levels across countries, taken from Penn World Tables version 9.0 (Feenstra et al., 2015).

${ }^{10}$ Rodrik (2018b) discusses how the income implications of globalization relate to the rise of populism using international trade theory. See also Hoekman, and Nelson (2018) and Mudambi (2018) for complementary analyses based on international business and global value chains.

${ }^{11}$ Note that GF income per capita is not equal to wage, it is a per capita measure of GF income that allows cross-country comparisons.

${ }^{12}$ All growth rates in this paper are expressed as average annual (compound) rates.

${ }^{13}$ Doing the same analysis for a smaller subset of emerging economies as in Baldwin (2016) (China, Korea, India, Poland, Indonesia), similar results are reached as both sets of countries are dominated by developments in India and China.

${ }^{14}$ In additional analyses, we have done a similar analysis for detailed manufacturing product groups

\section{REFERENCES}

Acemoglu, D., \& Robinson, J. A. 2012. Why nations fail: The origins of power, prosperity, and poverty. New York: Crown Business.

Altenburg, T., Schmitz, H., \& Stamm, A. 2008. Breakthrough? China's and India's transition from production to innovation. World Development, 36(2): 325-344.

Ali-Yrkkö, J., Rouvinen, P., Seppälä, T., \& Ylä-Anttila, P. 2011. Who captures value in global supply chains? Case NOKIA N95 and found similar trends for most products. We also have split KI activities into upstream and downstream activities on the basis of the occupation of workers. This is a more refined test of a "deepening" of the smile curve. We find that the importance of both upstream and downstream activities increased at the aggregate and for most product groups.

${ }^{15}$ Major in the sense that these are the product groups with the highest global final output amongst the set of 18 (2-digit) product groups for which we have data.

${ }^{16} \mathrm{~A}$ final product is consumed, which contrasts with intermediate inputs that are used further in the production process.

${ }^{17}$ This income decomposition method has also been used in Timmer et al. (2014), and is discussed in Johnson (2017). Related applications that map final output to value added can be found in Johnson and Noguera (2012) and Herrendorf, Rogerson, and Valentinyi (2013). The method provides empirical content to the concepts of a 'value system', as defined by Porter, 1990), or a 'global value network' (Chaminade \& Vang, 2008).

${ }^{18}$ This is under empirically mild conditions, see Miller \& Blair (2009) for an introduction to inputoutput analysis.

19. The EU Labour Force Surveys do not provide information on wage incomes, and we complement this with information from the EU Structure of Earnings Surveys. For China, we obtain wage data from the China Household Income Project surveys. For Japan, we use Wage structure surveys. Other countries provide wage and employment information in the same data source.

${ }^{20}$.For example, the correspondence table between the Australian Standard Classification of Occupations (ANZSCO) and ISCO 88 can be found at: https://www.abs.gov.au/AUSSTATS/abs@.nsf/ DetailsPage/1220.0First\%20Edition,\%20Revision\% 201? OpenDocument.

smartphone. Journal of Industry, Competition, and Trade, 11(3): 263-278.

Alvaredo, F., Chancel, L., Piketty, T., Saez, E., \& Zucman, G. 2017. World inequality report, 2018. World Inequality Lab.

Amokuse, T. O., \& Yin, H. 2010. Intellectual property rights protection and the surge in FDI in China. Journal of Comparative Economics, 38(2): 217-224. 
Amsden, A. H., \& Tschang, F. T. 2003. A new approach to assessing the technological complexity of different categories of R\&D (with examples from Singapore). Research Policy, 32(4): 553-572.

Autor, D. 2015. Why are there still so many jobs? The history and future of workplace automation. Journal of Economic Perspectives, 103(6): 2121-2168.

Awate, S., \& Mudambi, R. 2018. On the geography of emerging industry technology networks: The breadth and depth of patented innovations. Journal of Economic Geography, 18(2): 391-419.

Awate, S., Larsen, M. M., \& Mudambi, R. 2012. EMNE catch-up strategies in the wind turbine industry: Is there a trade-off between output and innovation capabilities? Global Strategy Journal, 2(3): 205-223.

Awate, S., Larsen, M. M., \& Mudambi, R. 2015. Accessing vs sourcing knowledge: A comparative study of $R \& D$ internationalization between emerging and advanced economy firms. Journal of International Business Studies, 46(1): 6386.

Baldwin, R. 2016. The great convergence: Information technology and the new globalization. Cambridge, MA: Belknap.

Baldwin, R. E., \& Evenett, S. J. 2015. Value creation and trade in 21 st century manufacturing. Journal of Regional Science, 55(1): 31-50.

Bartels, F. L., Voss, H., Lederer, S., \& Bachtrog, C. 2012. Determinants of national innovation systems: Policy implications for developing countries. Journal of Innovation Organization \& Management, 14(1): 2-18.

Baumol, W. J. 1986. Productivity growth, convergence, and welfare: What the long-run data show. The American Economic Review, 76(5): 1072-1085.

Belderbos, R., Leten, B., \& Suzuki, S. 2013. How global is R\&D? Firm-level determinants of home-country bias in R\&D. Journal of International Business Studies, 44(8): 765-786.

Belderbos, R., Lokshin, B., \& Sadowski, B. 2015. The returns to foreign R\&D. Journal of International Business Studies, 46(4): 491-504.

Belderbos, R., Sleuwaegen, L., Somers, D., \& De Backer, K. 2016. Where to locate innovative activities in global value chains. OECD Science, Technology and Industry Policy Papers, number 30 .

Bernard, A. B., \& Fort, T. C. 2015. Factoryless goods producing firms. American Economic Review, 105(5): 518-523.

Bissell-Linsk, J. 2017. Nike's focus on robotics threatens Asia's low-cost workforce: Developing countries at risk of losing cheap manufacturing if leisurewear companies accelerate automation. Financial Times, 22 October.

Bowen, H. P., \& De Clercq, D. 2008. Institutional context and the allocation of entrepreneurial effort. Journal of International Business Studies, 39(4): 747-767.

Buckley, P. J. 2009a. The impact of the global factory on economic development. Journal of World Business, 44(2): 131143.

Buckley, P. J. 2009b. Internalisation thinking: From the multinational enterprise to the global factory. International Business Review, 18(3): 224-235.

Buckley, P. J. 2011. International integration and coordination in the global factory. Management International Review, 51(2): 269-283.

Buckley, P. J. 2018. Towards a theoretically-based global foreign direct investment policy regime. Journal of International Business Policy, 1(3): 184-207.

Buckley, P. J., \& Ghauri, P. N. 2004. Globalisation, economic geography and the strategy of multinational enterprises. Journal of International Business Studies, 35(2): 81-98.

Buckley, P. J., \& Strange, R. 2015. The governance of the global factory: Location and control of world economic activity. Academy of Management Perspectives, 29(2): 237-249.
Bulman, D., Eden, M., \& Nguyen, H. 2017. Transitioning from low-income growth to high-income growth: Is there a middleincome trap? Journal of the Asia Pacific Economy, 22(1): 5-28.

Carlsson, B. 2006. Internationalization of innovation systems: A survey of the literature. Research Policy, 35(1): 56-67.

Castellani, D., Jimenez, A., \& Zanfei, A. 2013. How remote are R\&D labs? Distance factors and international innovative activities. Journal of International Business Studies, 44(7): 649_ 675.

Castellani, D., \& Pieri, F. 2013. R\&D offshoring and the productivity growth of European regions. Research Policy, 42(9): 1581-1594.

Chaminade, C., \& Vang, J. 2008. Globalisation of knowledge production and regional innovation policy: Supporting specialized hubs in the Bangalore software industry. Research Policy, 37(10): 1684-1696.

Chen, W., Los, B., \& Timmer, M. P. 2018. Factor incomes in global value chains: The role of intangibles. National Bureau of Economic Research Working paper no. 25242.

Child, J., \& Rodrigues, S. B. 2005. The internationalization of Chinese firms: A case for theoretical extension? Management and Organization Review, 1(3): 381-410.

Choksy, U. S., Sinkovics, N., \& Sinkovics, R. R. 2017. Exploring the relationship between upgrading and capturing profits from GVC participation for disadvantaged suppliers in developing countries. Canadian Journal of Administrative Sciences, 34: 354-386.

Coff, R. W. 1999. When competitive advantage doesn't lead to performance: The resource-based view and stakeholder bargaining power. Organization Science, 10(2): 119-133.

Cohen, W., \& Levinthal, D. 1990. Absorptive capacity: A new perspective on learning and innovation. Administrative Science Quarterly, 35(1): 128-152.

Crespo, N., \& Fountoura, M. P. 2007. Determinant factors of FDI spillovers: What do we really know? World Development, 35(3): 410-425.

Crozet, M., \& Milet, E. 2017. Should everybody be in services? The effect of servitization on manufacturing firm performance. Journal of Economics \& Management Strategy, 26(4): 820-841.

Dao, M. C., Das, M., Koczan, Z., \& Lian, W. 2017. Why is labor receiving a smaller share of global income? Theory and empirical evidence. IMF Working paper WP/17/169.

Dedrick, J., Kraemer, K. L., \& Linden, G. 2010. Who profits from innovation in global value chains? A study of the iPod and notebook PCs. Industrial and Corporate Change, 19(1): 81116.

Denicolai, S., Strange, R., \& Zucchella, A. 2015. The dynamics of the outsourcing relationship. In R. Van Tulder, A. Verbeke \& R. Drogendijk (Eds), Multinational enterprises and their organizational challenges, pp. 341-364. Progress in international business research, vol. 10. Bingley: Emerald.

Di Gregorio, D., Musteen, M., \& Thomas, D. 2009. Offshoring as a source of international competitiveness for SMEs. Journal of International Business Studies, 40(6): 969-988.

Dietzenbacher, E., Los, B., Stehrer, R., Timmer, M. P., \& de Vries, G. J. 2013. The construction of world input-output tables in the WIOD project. Economic Systems Research, 25(1): 71-98.

Dixon, S., \& Meyer, K. 2014. Building dynamic capabilities of adaptation and innovation. Long Range Planning, 47(4): 186204.

Dossani, R., \& Kenney, M. 2007. The next wave of globalization: Relocating service provision to India. World Development, 35(5): 772-791.

Dunning, J. H., \& Lundan, S. 2008. Multinational enterprises and the global economy. Cheltenham: Edward Elgar.

Edquist, C. 1997. Systems of innovation: Technologies, institutions, and organizations. London: Routledge.

Eichengreen, B., Park, D., \& Shin, K. 2014. Growth slowdowns redux. Japan and the World Economy, 32: 65-84. 
Elia, S., Munjal, S., \& Scalera, V. G. 2016. Technology sourcing through licensing-in foreign technologies: Benefits for emerging market firms. Academy of Management Proceedings, 1: 17514.

European Commission, IMF, OECD, UN and World Bank. 2009. System of National Accounts 2008. New York, USA.

Evenson, R. E. 1990. Intellectual property rights, R\&D, inventions, technology purchase, and piracy in economic development. In R. E. Evenson \& G. Ranis (Eds), Science and technology: Lessons for policy: 325-356. Boulder: Westview.

Fagerberg, J., Srholec, M., \& Verspagen, B. 2010. Innovation and economic development. In B. H. Hall \& N. Rosenberg (Eds), Handbook of the economics of innovation, vol. 2: 833872. Amsterdam: North-Holland.

Fan, D., Li, Y., \& Chen, L. 2017. Configuring innovative societies: The crossvergent role of cultural and institutional varieties. Technovation, 66-67: 43-56.

Feenstra, R. C., Inklaar, R., \& Timmer, M. P. 2015. The next generation of the Penn World Table. American Economic Review, 105(10): 3150-3182.

Figueiredo, P. N. 2002. Does technological learning pay off? Inter-firm differences in technological capability-accumulation paths and operational performance improvement. Research Policy, 31(1): 73-94.

Fontagné, L., \& Harrison, A. (Eds). 2017. The factory-free economy: Outsourcing, servitization, and the future of industry. Oxford: Oxford University Press.

Fu, X., Piterobelli, C., \& Soete, L. 2011. The role of foreign technology and indigenous innovation in the emerging economies: Technological change and catching-up. World Development, 39(7): 1204-1212.

Gereffi, G., \& Fernandez-Stark, K. 2016. Global value chain analysis: A primer. Second Edition. Duke University, mimeo.

Gereffi, G. 2018. Global value chains and development: Redefining the contours of 21st Century capitalism. Cambridge: Cambridge University Press.

Gereffi, G. 2019. Global value chains and international development policy: Bringing firms, networks and policy-engaged scholarship back in. Journal of International Business Policy, 2(3): 195-210.

Goos, M., Manning, A., \& Salomons, A. 2014. Explaining job polarization: Routine-biased technological change and offshoring. American Economic Review, 104(8): 2509-2526.

Gospel, H., \& Sako, M. 2008. The unbundling of corporate functions: The evolution of shared services and outsourcing in human resource management. Industrial and Corporate Change, 19(5): 1367-1396.

Hanson, G. H. 2012. The rise of middle kingdoms: Emerging economies in global trade. Journal of Economic Perspectives, 26(2): 41-64.

Haskel, J., \& S. Westlake. 2018. Capitalism without capital: The rise of the intangible economy. Princeton: Princeton University Press.

Hausmann, R., \& Rodrik, D. 2003. Economic development as self-discovery. Journal of Development Economics, 72(2): 603633.

Hennart, J.-F. 2009. Down with MNE-centric theories! Market entry and expansion as the bundling of MNE and local assets. Journal of International Business Studies, 40(9): 1432-1454.

Hennart, J.-F. 2012. Emerging market multinationals and the theory of the multinational enterprise. Global Strategy Journal, 2(3): 168-187.

Henisz, W. J. 2000. The institutional environment for multinational investment. Journal of Law Economics and Organization, 16(2): 334-364.

Henisz, W. J., \& Swaminathan, A. 2008. Institutions and international business. Journal of International Business Studies, 39(4): 537-539.

Herrendorf, B., Rogerson, R., \& Valentinyi, Á. 2013. Two perspectives on preferences and structural transformation. American Economic Review, 103(7): 2752-2789.
Hobday, M. 2001. The electronics industries of the AsiaPacific: Exploiting international production networks for economic development. Asian-Pacific Economic Literature, 15(1): 13-29.

Hoekman, B., \& Nelson, D. R. 2018. Reflecting on populism and the economics of globalization. Journal of International Business Policy, 1(1-2): 34-43.

Holmes, R. M., Jr., Miller, T., Hitt, M. A., \& Salmador, M. P. 2013. The interrelationships among informal institutions, formal institutions, and inward foreign direct investment. Journal of Management, 39(2): 531-566.

Hoskisson, R. E., Eden, L., Lau, C.-M., \& Wright, M. 2000. Strategy in emerging economies. Academy of Management Journal, 43(3): 249-267.

Johnson, R.C. 2017. Measuring global value chains. National Bureau of Economic Research, Working Paper no. 24027.

Johnson, R. C., \& Noguera, G. 2012. Accounting for intermediates: Production sharing and trade in value added. Journal of International Economics, 86: 224-236.

Jones, G. 2017. Business history, the great divergence and the great convergence. Harvard Business School, Working Paper no. 18-004.

Kano, L. 2018. Global value chain governance: A relational perspective. Journal of International Business Studies, 49(6): 684-705.

Kim, L. 1998. Crisis construction and organizational learning: Capability building in catching-up at Hyundai Motor. Organization Science, 9(4): 506-521.

Kaplan, D., \& Kaplinsky, R. 1999. Trade and industrial policy on an uneven playing field: The case of the deciduous fruit canning industry in South Africa. World Development, 27(10): 1787-1801.

Kelle, M. 2013. Crossing industry borders: German manufacturers as services exporters. The World Economy, 36(12): 14941515.

Khanna, T., \& Palepu, K. G. 1997. Why focused strategies may be wrong for emerging markets. Harvard Business Review, 75(4): 41-51.

Khoury, T. A., \& Peng, M. W. 2011. Does institutional reform of intellectual property rights lead to more inbound FDI? Evidence from Latin America and the Caribbean. Journal of World Business, 46(3): 337-345.

Kobrin, S. J. 2018. Global production networks, territoriality, and political authority. In R. E. Grosse \& K. E. Meyer (Eds), The Oxford handbook of management in emerging markets: 333 350. Oxford: Oxford University Press.

Kumaraswamy, A., Mudambi, R., Saranga, H., \& Tripathy, A. 2012. Catch-up strategies in the Indian auto-components industry: Domestic firms' responses to market liberalization. Journal of International Business Studies, 43(4): 368-395.

Lall, S. 1992. Technological capabilities and industrialization. World Development, 20(2): 165-186.

Lall, S. 1993. Understanding technology development. Development and Change, 24(4): 719-753.

Leonard-Barton, D. 1992. Core capabilities and core rigidities: A paradox in managing new product development. Strategic Management Journal, 13(S1): 111-125.

Levinthal, D. A., \& March, J. G. 1993. The myopia of learning Strategic Management Journal, 14(Winter): 95-112.

Levy, D. L. 2008. Political contestation in global production networks. Academy of Management Review, 33(4): 943-963.

Lewin, A. Y., Kenney, M., \& Murmann, J. P. (Eds). 2016. China's innovation challenge: Overcoming the middle-income trap. Cambridge: Cambridge University Press.

Lewin, A. Y., Massini, S., \& Peeters, C. 2009. Why are companies offshoring innovation? The emerging global race for talent. Journal of International Business Studies, 40(6): 901-925.

Li, J., \& Kozhikode, R. K. 2009. Developing new innovation models: Shifts in the innovation landscape in emerging economies and implications for global $R \& D$ management. Journal of International Management, 15(3): 328-339. 
Linden, G., Dedrick, J., \& Kraemer, K. L. 2011. Innovation and job creation in a global economy: The case of Apple's iPod. Journal of International Commerce and Economics, 3(1): 223-239.

Lorenzen, M., \& Mudambi, R. 2013. Clusters, connectivity and catch-up: Bollywood and Bangalore in the global economy. Journal of Economic Geography, 13(3): 501-534.

Los, B., Timmer, M. P., \& de Vries, G. J. 2015. How global are global value chains? A new approach to measure international fragmentation. Journal of Regional Science, 55(1): 66-92.

Luo, Y., \& Tung, R. L. 2007. International expansion of emerging market enterprises: A springboard perspective. Journal of International Business Studies, 38(4): 481-498.

Lundvall, B.-A. (Ed). 1992. National systems of innovation: Towards a theory of innovation and interactive learning. London: Pinter.

Lundvall, B.-A. 2007. National innovation systems: Analytical concept and development tool. Industry \& Innovation, 14(1): 95-119.

Maskus, K. 2000. Intellectual property rights in the global economy. Washington DC: Institute for International Economics.

Mathews, J. A. 2006. Dragon multinationals: New players in 21st century globalization. Asia Pacific Journal of Management, 23(1): 5-27.

Meyer, K. E., \& Peng, M. W. 2016. Theoretical foundations of emerging economy business research. Journal of International Business Studies, 47(1): 3-22.

Miller, R. E., \& Blair, P. D. 2009. Input-output analysis: Foundations and extensions. Cambridge: Cambridge University Press.

Mudambi, R. 2008. Location, control and innovation in knowledge-intensive industries. Journal of Economic Geography, 8(5): 699-725.

Mudambi, R. 2018. Knowledge-intensive intangibles, spatial transaction costs, and the rise of populism. Journal of International Business Policy, 1(1-2): 44-52.

Mudambi, R., \& Puck, J. 2016. A global value chain analysis of the 'regional strategy' perspective. Journal of Management Studies, 53(6): 1076-1093.

Nieto, M. J., \& Rodríguez, A. 2011. Offshoring of R\&D: looking abroad to improve innovation performance. Journal of International Business Studies, 42(3): 345-361.

North, D. C. 1991. Institutions. Journal of Economic Perspectives, 5(1): 97-112.

Palpacuer, F. 2008. Bringing the social context back in: Governance and wealth distribution in global commodity chains. Economy and Society, 37(3): 393-419.

Papanastassiou, M., Pearce, R., \& Zanfei, A. 2019. Changing perspectives on the internationalization of $R \& D$ and innovation by multinational enterprises: A review of the literature. Journal of International Business Studies, forthcoming.

Park, A., Nayyar, G., \& Low, P. 2013. Supply chain perspectives and issues: A literature review. Hong Kong: Fung Global Institute and World Trade Organization.

Peng, M. W., Wang, D. Y. L., \& Jiang, Y. 2008. An institutionbased view of international business strategy: A focus on emerging economies. Journal of International Business Studies, 39(5): 920-936.

Pilat, D., Cimper, A., Olsen, K., \& Webb, C. 2008. The changing nature of manufacturing in OECD economies. In OECD, Staying competitive in the global economy: Compendium of studies on global value chains. Paris: OECD.

Porter, M. E. 1990. The competitive advantage of nations. New York: Free Press.

Puffer, S. M., McCarthy, D. J., \& Boisot, M. 2010. Entrepreneurship in Russia and China: The impact of formal institutional voids. Entrepreneurship Theory and Practice, 34(3): 441-467.
Pyndt, J. \& Pedersen, T. 2006. Managing global offshoring strategies: A case approach. Copenhagen: Copenhagen Business School.

Reimann, F., \& Ketchen, D. J., Jr. 2017. Power in supply chain management. Journal of Supply Chain Management, 53(2): 3

Reijnders, L. S., \& de Vries, G. J. 2018. Technology, offshoring and the rise of non-routine jobs. Journal of Development Economics, 135: 412-432.

Rodrik, D. 2012. Unconditional convergence in manufacturing. The Quarterly Journal of Economics, 128(1): 165-204.

Rodrik, D. 2014. The past, present, and future of economic growth. Challenge, 57: 5-39.

Rodrik, D. 2018a. New technologies, global value chains, and developing economies. NBER Working paper no. 25164.

Rodrik, D. 2018b. Populism and the economics of globalization. Journal of International Business Policy, 1(1-2): 12-33.

Samara, E., Georgiadis, P., \& Bakouros, I. 2012. The impact of innovation policies on the performance of national innovation systems: A system dynamics analysis. Technovation, 32(11): 624-638.

Seyoum, B. 1996. The impact of intellectual property rights on foreign direct investment. Columbia Journal of World Business, 31(1): 50-59.

Smarzynska, B.K. 2002. Composition of foreign direct investment and protection of intellectual property rights: Evidence from transition economies. Washington DC: World Bank, Policy Research Working Paper no. 1786.

Strange, R., \& Humphrey, J. 2019. What lies between market and hierarchy? Insights from internalization theory and global value chain theory. Journal of International Business Studies, 50(8): 1401-1413.

Strange, R., \& Zucchella, A. 2017. Industry 4.0, global value chains and international business. Multinational Business Review, 25(3): 174-184.

Teece, D. I. 1986. Profiting from technological innovation: Implications for integration, collaboration, licensing and public policy. Research Policy, 15(6): 285-305.

Timmer, M. P., Erumban, A. A., Los, B., Stehrer, R., \& de Vries, G. J. 2014. Slicing up global value chains. Journal of Economic Perspectives, 28(2): 99-118.

Timmer, M. P., Dietzenbacher, E., Los, B., Stehrer, R., \& de Vries, G. J. 2015. An illustrated user guide to the world input-output database: The case of global automotive production. Review of International Economics, 23(3): 575-605.

Timmer, M. P., Miroudot, S., \& de Vries, G. J. 2019. Functional specialisation in trade. Journal of Economic Geography, 19(1): $1-30$.

Turkina, E., \& Van Assche, A. 2018. Global connectedness and local innovation in industrial clusters. Journal of International Business Studies, 49(6): 706-728.

Westphal, L. E. 1982. Fostering technological mastery by means of selective infant-industry protection. In M. Syrquin \& S. Teitel (Eds), Trade, stability, technology, and equity in Latin America: 255-279. New York: Academic Press.

World Bank. 2017. Measuring and analyzing the impact of GVCs on economic development. Global value chain development report 2017. Washington DC: World Bank.

Wright, M., Filatotchev, I., Hoskisson, R. E., \& Peng, M. W. 2005. Strategy research in emerging economies: Challenging the conventional wisdom. Journal of Management Studies, 42(1): 1-33.

Zanello, G., Fu, X., Mohnen, P., \& Ventresca, M. 2015. The creation and diffusing of innovation in developing countries: A systematic literature review. Journal of Economic Surveys, 30(5): 884-912. 


\section{APPENDIX A: TRACING INCOME IN THE GLOBAL FACTORY: METHOD}

Our approach, while mathematically involved and highly data-intensive, has a very clear intuition: it is grounded in the basic accounting identity that the value of a good is equal to the remuneration for all factors of production that have been involved in its production. This is a cornerstone of the economic statistics regularly produced by national statistical organizations according to the internationally harmonized System of National Accounts (SNA). Los et al. (2015) present a model that shows that this insight can also be usefully applied in the context of cross-border production systems. They proposed a new method to track the incomes that are earned in all stages of production of a final good, anywhere in the world. ${ }^{16}$ It considers incomes not only in the manufacturing sector that finalizes the good but also in supporting industries such as business, transport and communication and financial services through the delivery of intermediate inputs. These indirect contributions are explicitly accounted for through the modellng of input-output linkages across sectors. We follow the method by Los et al. (2015) and extend their model to account for value-added as well as labor incomes. The model quantifies the network structure of the global economy and thus provides an excellent instrument to trace incomes generated in the GF. ${ }^{17}$

We follow the recent model of Los et al. (2015) which shows that by modeling the world economy as an input-output model, one can trace the amount of factor inputs needed to produce a final manufacturing good. The starting point is the final output of a particular good (say iPhones finalized in China). A final product is consumed, which contrasts with intermediate inputs that are used further in the production process. Let $Z$ be a vector column of which the first element representing the global consumption of iPhones produced in China, and all other elements are zero. Then, $\mathrm{BZ}$ is the vector of intermediate inputs, both Chinese and foreign, needed to assemble the iPhones in China, such as the hard-disc drive, battery and processors. $B$ is a matrix with intermediate input coefficients that describe how much intermediates are needed to produce a unit of output of a given product. However, these intermediates need to be produced as well, and $\mathrm{B}^{2} \mathrm{Z}$ indicates the intermediate inputs directly needed to produce BZ. This continues until the mining and drilling of basic materials, such as the metal ore, sand and oil required to start the production process. Summing up across all stages, one derives the gross outputs generated in the production of a iPhone by $(I-B)^{-1} Z$, with I a square matrix in which all the elements of the principal diagonal are ones and all other elements are zeros. This is so because the summation across all rounds $\left(\mathrm{BZ}+\mathrm{B}^{2} \mathrm{Z}+\mathrm{B}^{3} \mathrm{Z}+\ldots\right)$ converges to $(I-B)^{-1} Z{ }^{18}$ Put otherwise, it shows the output in all industries around the world that participate in the GF of the good.

To find the labor income by workers in this GF, we additionally need the share of wages in gross output represented in matrix $F$. These shares are country-, industry- and worker-specific, for example, wages paid to fabrication workers in the Chinese electronics industry. To find the labor incomes by all workers in the GF, we multiply $F$ by the total gross output value in all stages of production, $K=F Q$ and given above: $K=F(I-B)^{-1} Z$. A typical element in matrix $K$ indicates the labor income of a worker $f$ located in country $l$ in the production of final good $z$. We use our occupational statistics to further split the labor income into fabrication and $\mathrm{KI}$ activities.

\section{APPENDIX B: CONSTRUCTION OF THE OCCUPATIONS DATABASE}

We collected our data on occupations by bringing together and harmonizing labor force statistics from the various countries. Depending on the data availability in a country, we use annual labor force surveys or quinquennial (or decadal) population censuses. These data have been collected by national statistical offices at the level of individuals in a nationally representative survey. In the case of census data, the sample is the whole population, which is the ideal case. In the case of a sample survey, the national statistical institute will apply a stratified sampling approach and gross-up the 
Table 2 Data sources for the Occupations Database

\begin{tabular}{lll}
\hline Country & Source(s) & Years \\
\hline Australia & Labor force: employed persons quarterly large source dataset & $1997-2011$ \\
Brazil & National household sample survey (PNAD) & $1995-2014$ \\
Canada & Canadian labor force survey & $1995-2014$ \\
China & Population census & 2000,2010 \\
& CHIP survey & 2002,2013 \\
EU members ${ }^{a}$ & Labour force survey & $1995-2013$ \\
& Structure of earnings survey & 2002,2006, and 2010 \\
India & National sample survey & $2000,2004-2006,2008,2011$ \\
Indonesia & National labor force survey (Sakernas) & $2002-2014$ \\
Japan & Population census, wage structure surveys & $1995,2000,2005,2010$ \\
Mexico & Population census & 2000,2010 \\
Russia & Labor force survey & $2000,2008,2012$ \\
South Korea & Korea Labor and Income Panel Study (KLIPS) & $1998-2012$ \\
Taiwan & Manpower survey & $1995-2014$ \\
Turkey & Labor force survey & $2006-2013$ \\
United States & Population census & 2000 \\
& American community surveys & $1997-1999,2000-2014$ \\
\hline
\end{tabular}

a The 27 countries that were members of the EU per January 2007.

b Bulgaria and Malta from 2000 onwards; Poland from 2004 onwards.

results to the overall population. Thus, they can be used in conjunction with the census data, and both survey and census data can be used with the national accounts data underlying the WIOD. The methodology for harmonization is identical to the one described in Reijnders and de Vries (2018) and Timmer et al. (2019). For the purpose of this paper, we updated the data from 2011 to 2014 using the same methodology discussed in more detail below.

In our choice of data sources, we follow previous research that studied occupational structures in the economy. For example, for the United States, we use the same data sources as Autor (2015), namely the 2000 Current Population Census and the annual American Community Surveys. Data for European countries comes from the harmonized individual-level European Union Labour Force Surveys, which are also used by Goos, Manning, and Salomons (2014). ${ }^{19}$ The European Labour Force Surveys were collected and processed by Eurostat. For China, the National Bureau of Statistics processed the data and provided detailed tabulations. For other countries, the data collection is often publicly available. For example, the statistical office of Brazil publishes all the data from the National Household Sample Surveys online.
A major challenge is the creation of consistent time series. Once we identify the main data source for a country, we use the same source throughout if possible. This approach assures intertemporal consistency. For most countries, we either have a time series or data for a year close to the starting year (1995) and ending year (2014) of the analysis; see Appendix Table 2 for an overview. If we do not have information for a given year, then we use interpolation and/or extrapolation. We followed standard procedures using an updating procedure that takes account of the three-dimensional nature of the data (industry, occupational class and year), making it consistent with the WIOD.

To create international consistency, we harmonized the data sources across countries by making two mappings. First, national industry classifications are mapped to a common set of 56 industries according to the International Standard Industrial Classification (ISIC) revision 4 . These include agriculture, mining, construction, utilities, 18 manufacturing industries, telecom, finance, business services, personal services, trade and transport services industries and public services industries, together covering the overall economy. These industries are chosen so that they coincide with those distinguished in the WIOD, release 2016. Second, national occupation classifications are 
mapped to a single classification consisting of 13 different occupations; see Table 1 in Reijnders and de Vries (2018). The choice of 13 occupations by Reijnders and de Vries (2018) was guided by the motivation to have as much detail as possible while at the same time minimizing the amount of classification errors and maximizing cross-country harmonization. The classification relates most naturally to the International Standard Classification of Occupations (ISCO), and the corresponding 2digit (and occasionally 3-digit) codes are listed in Table 1 of Reijnders and de Vries (2018). For example, the occupation 'Managers' corresponds to ISCO 88 codes 12 and 13, and 'Clerical workers' to codes 41 and 42. Statistical offices provide crosswalks from national occupation classifications to ISCO 88 to comply with data requests from the United Nations and the International Labour Organization. ${ }^{20}$ In a final step, we aggregated the 13 occupational groupings to two categories, namely fabrication and KI occupations. For fabrication, we used the ISCO 88 codes 61-62, 71-74, 81-82, 92 and 93. For KI workers, we used the other occupational groupings.

See Table 3.

Table 3 Mapping of occupations to activities

\begin{tabular}{lll}
\hline $\begin{array}{l}\text { Type of } \\
\text { activity }\end{array}$ & Includes & Occupations \\
\hline $\begin{array}{ll}\text { Knowledge } \\
\text { intensive }\end{array}$ & $\begin{array}{l}\text { R\&D, design, commercialization, engineering, marketing, } \\
\text { advertising and brand management, specialized logistics, and } \\
\text { activities }\end{array}$ & $\begin{array}{l}\text { Professionals; technicians and associate } \\
\text { professionals; clerks; senior officials and managers }\end{array}$ \\
$\begin{array}{ll}\text { Production } \\
\text { activities }\end{array}$ & $\begin{array}{l}\text { Assembly, parts and components manufacturing, } \\
\text { standardized services }\end{array}$ & $\begin{array}{l}\text { Plant and machine operators and assemblers; craft } \\
\text { and related trades workers; service workers and shop } \\
\text { and market sales workers; elementary occupations }\end{array}$
\end{tabular}

Occupation descriptions based on the International Standard Classification of Occupations 1988.

\section{ABOUT THE AUTHORS}

Peter J. Buckley OBE, FBA, is Professor of International Business, Founder Director of the Centre for International Business, University of Leeds (CIBUL). Founder Director of the Business Confucius Institute at the University of Leeds and Cheung Kong Scholar Chair Professor in the University of International Business and Economics (UIBE), Beijing. President of the Academy of International Business 2002-2004.

Roger Strange is Professor of International Business, University of Sussex. He is a former President of the European International Business Academy, and is Associate Editor of the International Business Review, Senior Editor of the Asia Pacific Journal of Management, and on the Editorial Boards of the Global Strategy Journal, the Asia Pacific Business Review, and the Journal of Management \& Governance.

Marcel P. Timmer is Professor in Economics at the University of Groningen and director of the Groningen Growth and Development Centre (GGDC). Since September 2019, he has also been Deputy-Director of the CPB Netherlands Bureau of Economic Policy Analysis. He has published extensively in major academic journals on issues of economic growth, structural change, international trade, productivity and economic statistics.

Gaaitzen J. de Vries is Associate Professor at the University of Groningen, visiting Professor of Global Value Chains at the University of International Business and Economics (UIBE). His research fits in the fields of International Economics and Development Economics and appeared in the American Economic Review, the Journal of Economic Perspectives, and the Journal of Development Economics.

Open Access This article is licensed under a Creative Commons Attribution 4.0 International License, which permits use, sharing, adaptation, distribution and reproduction in any medium or format, as long as you give appropriate credit to the original author(s) and the source, provide a link to the Creative Commons licence, and indicate if changes were made. The images or other third party material in this article are included in the article's Creative Commons licence, unless indicated otherwise in a credit line to the material. If material is not included in the article's Creative Commons licence and your 
view a copy of this licence, visit http://creative commons.org/licenses/by/4.0/ intended use is not permitted by statutory regulation or exceeds the permitted use, you will need to obtain permission directly from the copyright holder. To

Publisher's Note Springer Nature remains neutral with regard to jurisdictional claims in published maps and institutional affiliations.

Accepted by Ram Mudambi, Area Editor, 19 December 2019. This article has been with the authors for two revisions. 